\title{
Molecular biochemical aspects of salt (sodium chloride) in inflammation and immune response with reference to hypertension and type 2 diabetes mellitus
}

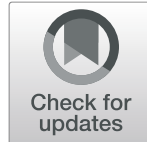

Undurti N. Das (D)

\begin{abstract}
Obesity, insulin resistance, type 2 diabetes mellitus (T2DM) and hypertension (HTN) are common that are associated with low-grade systemic inflammation. Diet, genetic factors, inflammation, and immunocytes and their cytokines play a role in their pathobiology. But the exact role of sodium, potassium, magnesium and other minerals, trace elements and vitamins in the pathogenesis of HTN and T2DM is not known. Recent studies showed that sodium and potassium can modulate oxidative stress, inflammation, alter the autonomic nervous system and induce dysfunction of the innate and adaptive immune responses in addition to their action on renin-angiotensinaldosterone system. These actions of sodium, potassium and magnesium and other minerals, trace elements and vitamins are likely to be secondary to their action on pro-inflammatory cytokines IL-6, TNF-a and IL-17 and metabolism of essential fatty acids that may account for their involvement in the pathobiology of insulin resistance, T2DM, HTN and autoimmune diseases.
\end{abstract}

Keywords: Hypertension, diabetes mellitus, inflammation, T cells, reactive oxygen species, sodium, potassium

\section{Introduction}

Both type 2 DM (T2DM) and hypertension (HTN) are common diseases in almost all countries of the world. It is estimated that about $50 \%$ of the population above the age of 45 years have HTN and another $10-20 \%$ of the population have T2DM (detected or undetected). Almost $50 \%$ of the patients who have T2DM have or develop HTN eventually. Thus, both T2DM and HTN are present in many of the patients (population). In addition, obesity is also common. Patients with both T2DM and HTN are generally obese. It is noteworthy that obesity, T2DM and HTN are all associated with insulin resistance. In fact, insulin resistance is the first to develop in those who eventually develop HTN and T2DM. It is

Correspondence: undurti@hotmail.com

UND Life Sciences, 2221 NW 5th St, Battle Ground, WA 98604, USA now recognised that obesity, T2DM and HTN are all low-grade systemic inflammatory conditions. Coronary heart disease (CHD) eventually occurs in some, if not all, of the patients with insulin resistance, obesity, T2DM and HTN. Thus, all these conditions have overlapping features and one condition may lead to the other(s) [18]. Insulin resistance seems to be a common factor underlying all these conditions.

Of all the dietary factors that are known to influence the development of HTN and T2DM, salt, potassium, essential fatty acids, minerals, trace elements, vitamins and calorie intake are important. Salt does not influence the development of HTN in all but in a subset of patients who have salt sensitive HTN, whereas potassium seems to suppress the pro-hypertensive action of salt $[9$, 10]. In addition to these dietary factors, exercise is also an equally important factor in the prevention and 
management of hypertension and T2DM. Sodium (salt) is an essential nutrient in man and physiological need in adults is only of the order of $8-10 \mathrm{mmol} /$ day $(184-230$ $\mathrm{mg} /$ day). It may be noted that the equivalence between sodium and salt is as follows: $1 \mathrm{~g}$ sodium chloride $=17.1$ mmol or 393.4 mg sodium. Salt intake induces a significant difference in the prevalence of hypertension. Higher intake of salt is expected to produce substantial increase in blood pressure, though some studies did not reproduce this correlation between salt intake and blood pressure (reviewed in ref. 2). This discrepancy could be attributed to variations in the consumption of other minerals such as potassium, magnesium, and calcium. It has been suggested that availability of adequate amounts of calcium stabilizes the cell membrane (such as endothelial and smooth muscle cell membranes), blocks its own entry into the cells, and makes arterial smooth muscle cells less likely to contract [2]. It was reported that hypertensives consume less sodium than those with normal blood pressure and significantly less calcium, potassium, vitamin A, and vitamin C [2]. In SHR (spontaneously hypertensive rat) showed a lower level of sodium contents in the RBC and a higher activity of the sodium pump. These studies led to the suggestion that the amounts of dietary calcium might regulate blood pressure by changing the sodium pump of the cell membrane in SHR. It is likely that it is not the calcium alone but calcium in conjunction with other ions such as sodium and potassium that relax the arterial smooth muscle cells. These results imply that it is likely that a balance between all the ions that is more important than calcium or for that matter any one ion in isolation that regulates the smooth muscle contraction and the development of hypertension [2].

It is well documented that increased consumption of high calorie diet or high fat diet (HFD) enhance the risk of development of insulin resistance, obesity, T2DM and HTN. Similarly, high dietary content of trans-fats and saturated fats enhance the incidence of insulin resistance, obesity and T2DM. In contrast to this, adequate exercise is beneficial in reducing the risk of insulin resistance, obesity, T2DM and HTN and consequently improve cardiovascular health. In addition, deficiency or sub-optimal intake of minerals, trace elements and vitamins increase the risk of development of obesity and T2DM [2]. Of all the dietary factors, perhaps, salt plays a dominant role in the pathobiology of insulin resistance, HTN and T2DM including cardiovascular health. In South Asian countries where salt intake is high, it may have a dominant role in the development of insulin resistance, HTN, T2DM and cardiovascular diseases. Despite this close association, the exact mechanism(s) by which salt plays a significant role in these diseases is not clear. It is suggested that high salt intake induces low- grade systemic inflammation, decreases NO and PGI2 generation, and thus, participates in the pathogenesis of these diseases. Based on the current evidence, it is proposed that high salt intake enhances the generation of TH17 cells that secrete enhanced amounts of IL-17, a pro-inflammatory molecule; suppresses the production of anti-inflammatory bioactive lipids (such as PGE1, PGI2, lipoxin A4, resolvins, protectins, and maresins). This imbalance between pro-inflammatory IL-17 (due to enhanced generation and activity of TH17 cells) and decreased production of anti-inflammatory bioactive lipids that have a negative regulatory control on IL- 6 and TNF- $\alpha$, results in an increase in the production of proinflammatory IL- 6 and TNF- $\alpha$, which induce the production of reactive oxygen species (ROS), reduce the generation of nitric oxide (NO) and enhance sympathetic activity. These events result in an increase in insulin resistance and subsequent development of HTN and T2DM. PGE1, PGI2, LXA4, resolvins, protectins and maresins, and $\mathrm{NO}$ are vasodilators and a decrease in their production/action results in an increase in peripheral vascular resistance and development of HTN [11]. Several studies showed that LXA4, resolvins, protectins and NO have anti-diabetic actions [12-17]. These results suggest that inflammation and immunological events participate in the development of HTN and DM implying that these two diseases have several common overlapping pathophysiological events.

Increased salt (sodium chloride) intake enhances the induction of human TH17 cells by activating the p38/ MAPK pathway and serum/ glucocorticoid-regulated kinase 1 (SGK1) [18] resulting in upregulation of the proinflammatory cytokines GM-CSF, TNF- $\alpha$, and IL-2 leading to the development of inflammatory events seen in HTN and T2DM. Thus, increased intake of salt induced SGK1 expression promotes IL-23R expression which enhances TH17 cell differentiation and accelerates the development of inflammatory events that can be suppressed by potassium supplementation [19]. These results imply that the balance between salt and potassium needs to be maintained to regulate TH17-induced inflammatory events, vascular tone, insulin resistance and prevent development of HTN and T2DM [2, 11, 20-22].

\section{Hypertension and T2DM have overlapping features}

Hypertension is common in many countries. It is estimated that the prevalence of hypertension among adults was $29.0 \%$ and was similar among men $(30.2 \%)$ and women $(27.7 \%)$ in USA. Approximately $\sim 50 \%$ of patients with T2DM have and/or develop HTN that enhances risk of vascular diseases (including coronary heart disease: CAD; peripheral vascular disease, stroke) due to DM. The risk for cardiovascular disease (CVD) is $\sim$ four-fold higher in those with both DM and HTN 
compared to the normotensive non-diabetics. DM enhances the risk for coronary heart disease (CAD), stroke and deaths from cardiovascular cause, including heart failure, cardiac arrhythmia, sudden death, hypertensive disease, and aortic aneurysms [8]. The enhanced risk of complications due to DM are common in those who also have HTN. Subjects who have both HTN and T2DM are generally older, have higher BMI and hypertriglyceridemia (and other lipid abnormalities). These patients have higher expression levels of NADPH oxidase and MnSOD in their peripheral blood mononuclear cells [23-26].

$\mathrm{NADPH}$ oxidase (nicotinamide adenine dinucleotide phosphate oxidase) is a plasma membrane-bound enzyme complex that is used by neutrophils to inactivate microorganisms by producing superoxide free radical. The NADPH oxidase complex is dormant under normal circumstances but is activated during respiratory burst. Superoxide anion kills bacteria directly by attenuating their superoxide dismutase (SOD) genes and generating hydrogen peroxide and other reactive oxygen species (ROS). These free radicals inactivate several metabolic enzymes, initiate lipid peroxidation, damage ironsulphur clusters, and allows the generation of indiscriminate oxidants. Vascular NADPH oxidases are important players in vascular remodeling and disease. Thrombin, platelet-derived growth factor (PDGF), tumor necrosis factor- $\alpha$ (TNF- $\alpha$ ), interleukin-1, oxidized LDL and arachidonic acid can activate NDPH oxidase [27-35]. In those with uncontrolled hypertension, there is increased generation of free radicals including superoxide anion by their peripheral leukocytes and endothelial cells that can be attenuated by various antihypertensive drugs [11, 3639]. It has been suggested that excess superoxide produced scavenges endothelial nitric oxide that, in turn, leads to the increased vascular smooth muscle contraction and hence to the elevated total peripheral resistance and development of HTN [40]. Similar increased production of free radicals has also been reported in those with T2DM and coronary heart disease [41-46].

Manganese-dependent superoxide dismutase (MnSOD) is an enzyme which is a member of the iron/manganese superoxide dismutase family that binds to the superoxide byproducts of oxidative phosphorylation and converts them to hydrogen peroxide and diatomic oxygen $\left(\mathrm{O}_{2}\right)$. Thus, MnSOD clears reactive oxygen species (ROS) and protects cells from apoptosis. Thus, MnSOD protects various cells/tissues from oxidative stress induced by various agents and from inflammatory cytokines [47, 48]. These results suggest that a balance need to be maintained between ROS and MnSOD (SOD exists in three different isoforms: SOD1, SOD2, and SOD3. SOD1 is distributed throughout the cell cytoplasm, nucleus and in the lumen between outer and inner membranes of mitochondria,
SOD2 isoforms are in matrix of mitochondria, while SOD3 is found mostly extracellularly) such that inappropriate apoptosis of cells would not occur due to excess production of ROS.

Since, ROS generation is increased in both T2DM and HTN [36-44], it may explain as to why the risk of development of T2DM is high in those who have HTN [4953]. These results [49-53] suggest that HTN and T2DM may have some common pathophysiological basis including an increase in free radical generation. Both T2DM and HTN are considered as low-grade systemic inflammatory conditions since their plasma concentrations of tumor necrosis factor- $\alpha$ (TNF- $\alpha$ ), interleukin- 6 (IL-6), and C-reactive protein (CRP) are higher compared to normal healthy control [53-57]. High salt intake enhances the risk of development of HTN and T2DM [58-60]. In addition, increased generation of ROS and low levels of plasma NO is present in this situation [11, 36-40]. Furthermore, high salt intake induced HTN is associated with increased sympathetic activity (and so enhanced production of noradrenaline and adrenaline), augmentation of intrarenal angiotensin II production, enhanced oxidative stress and inflammatory cytokines [61-64]. The pro-inflammatory action of enhanced sympathetic activity [65] may counteract the antiobesity action of sympathetic nervous system. In contrast to this, vagal acetylcholine, the principal neurotransmitter of the parasympathetic nervous system, has potent antiinflammatory actions $[66,67]$. In this context, the beneficial action of exercise is interesting. Sympathetic activity, ROS, plasma IL- 6 and TNF- $\alpha$ levels are increased during exercise that are pro-inflammatory in nature [68-75]. But regular exercise enhances parasympathetic activity and augments vagal tone that results in increased generation of acetylcholine that has anti-inflammatory actions [66, $67,69,70,76,77]$. Interestingly, regular exercise causes a gradual but sustained fall in the generation of IL- 6 and TNF- $\alpha$ and enhances the production of MnSOD leading to an increase in endogenous antioxidant capacity [7375]. This ultimately results in decrease of blood pressure, and protection from the development of T2DM and CHD [69, 70, 76, 77]. Thus, exercise is antiinflammatory in nature $[69,70]$.

\section{Sodium and potassium modulate inflammation}

High intake of sodium causes hypertension by volume expansion, altering the renin-angiotensin-aldosterone system (RAS), reducing endothelial NO generation, enhancing the formation of asymmetrical dimethyl arginine (ADMA), oxidative stress secondary to excessive production of ROS, inflammation, impaired insulin-mediated vasodilatation, increased sympathetic nervous system (SNS) activation, dysfunctional immune responses, and abnormal renal handling of sodium [2, 9, 11, 59-64]. 
Similar abnormalities are also present in T2DM [41-44, 57-61, 9, 23, 49]. These results are in support of the observation that expression of NADPH oxidase is increased in those with obesity, higher BMI and HTN and T2DM $[23,24]$. This enhanced generation of ROS in those with T2DM and HTN can be attributed to an increase in the concentrations of pro-inflammatory cytokines IL-6, TNF$\alpha$ and IL-17. In addition, angiotensin-II is a potent inducer of inflammation and generation of ROS that may explain as to how increase in intake of sodium-induced reninangiotensin-aldosterone system induces inflammation and ROS induction [78-81]. Angiotensin-II enhances the formation of ADMA (asymmetrical dimethylarginine), a potent inhibitor of endothelial nitric oxide generation [81]. Thus, high salt intake reduces NO generation, increases ROS generation, decreases microvascular antioxidant enzymes (especially $\mathrm{Cu} / \mathrm{Zn} \mathrm{SOD}$ activity) and thus, contributes to enhanced peripheral vascular resistance and development of hypertension [82-86].

Recent studies revealed that increased salt (sodium chloride) intake augments the activity of TH17 cells via the p38/MAPK pathway and serum/glucocorticoid-regulated kinase 1 (SGK1) [18] that results in upregulation of GM-CSF, TNF- $\alpha$ and IL-2 levels, which are all proinflammatory cytokines that may account for the proinflammatory status seen in HTN and T2DM. This ability of salt to augment pro-inflammatory events can be suppressed by adequate potassium supplementation [19, $87,88]$. This indicates that a balance needs to be maintained between salt and potassium to suppress inappropriate induction of TH17-induced inflammatory events so that an increase in vascular tone and insulin resistance does not occur that ultimately leads to the development of HTN and T2DM. Thus, maintenance of balance among sodium, potassium, magnesium, and calcium in the physiological range prevents the development of HTN and T2DM [2].

Magnesium is a co-factor needed for the normal physiological activity of desaturases [2, 89, 90] that are needed for the conversion of dietary essential fatty acids (EFAs): linoleic acid (LA) and alpha-linolenic acid (ALA) to their respective long-chain metabolites that have important actions in the pathobiology of HTN and T2DM (see Fig. 1 for metabolism of EFAs and interaction among EFAs and their metabolites and other soluble mediators involved in HTN and T2DM). In addition, sodium and potassium influence the metabolism of EFAs by virtue of their ability to alter (sodium enhances whereas potassium decreases) the concentrations of angiotensin-II. Increased formation of angiotensin-II augments the generation of ROS that inactivates desaturases and thus, decreases the formation of their long-chain metabolites (GLA, DGLA, AA, EPA and DHA) [91, 92] some of which are the precursors of lipoxins, resolvins, protectins and maresins that have vasodilator, platelet antiaggregatory, anti-diabetic and anti-inflammatory actions [93-96]. Sodium inhibits whereas potassium enhances the activities of desaturases and thus, influence the conversion of dietary LA and ALA to their respective long-chain metabolites GLA, DGLA, $\mathrm{AA}$ and EPA and DHA, the precursors of pro- and antiinflammatory prostaglandins (PGs), thromboxanes (TXs), leukotrienes (LTs), lipoxins resolvins, protectins and maresins. Sodium enhances the formation of PGs, TXs and LTs and blocks the formation of lipoxins, resolvins, protectins and maresins at least, in part, by inhibiting the generation of AA, EPA and DHA, whereas potassium shows opposite actions [97-106]. This may explain as to why excess salt consumption leads to pro-inflammatory status and development of HTN and T2DM.

\section{Potassium, sodium, and T cells}

Potassium ions are not only the most abundant cation in the body but are also capable of regulating $\mathrm{T}$ cell function. Most of the potassium ( $98 \%)$ is intracellular and only $(\sim 2 \%)$ a small portion of it is extracellular. In view of its actions on the cardiac muscle, the extracellular $\mathrm{K}^{++}$concentrations need to be tightly controlled. Under normal physiological conditions, sodium and potassium ions have opposite actions. Increased sodium chloride concentrations enhance the induction of TH17 cells by activating the p38/MAPK pathway and serum/glucocorticoid-regulated kinase 1 (SGK1) [18, 19, 87, 88, 107112]. These TH17 cells secrete large amounts of proinflammatory cytokines GM-CSF, TNF- $\alpha$ and IL-2 that coincided with severe forms of autoimmune disease such as experimental autoimmune encephalomyelitis (EAE). It is noteworthy that other dietary factors such as high-fat and cholesterol, high-protein, high-sugar, and frequent consumption of processed and 'fast foods' that contain significantly high amounts of salt (sodium chloride) not only promote obesity, metabolic syndrome, and cardiovascular diseases but also augment $\mathrm{T}_{\mathrm{H}} 17$ cell generation and production of IL-17 cytokine and thus, promote autoimmune diseases. Thus, increased dietary salt, high fat diet and high sugar all enhance the risk of developing obesity, HTN and T2DM and autoimmune diseases (such as rheumatoid arthritis, lupus, multiple sclerosis) through the induction of pathogenic TH17 cells [18, 107-113] whereas elevated intracellular $\mathrm{K}^{+}$concentration suppresses $\mathrm{T}$ cell function by inhibiting Akt and mTOR protein kinases [19, 88-90, 114, 115]. Hence, maintaining the balance between $\mathrm{Na}^{+}$and $\mathrm{K}^{+}$across the cell membrane is critical not only for $\mathrm{T}$ cell function but also for other cells such as endothelial cells to prevent inappropriate production of pro-inflammatory cytokines (endothelial cells also produce cytokines [116]). Thus, dietary salt and $\mathrm{K}^{+}$intake modulate GM-CSF, TNF- $\alpha$, 


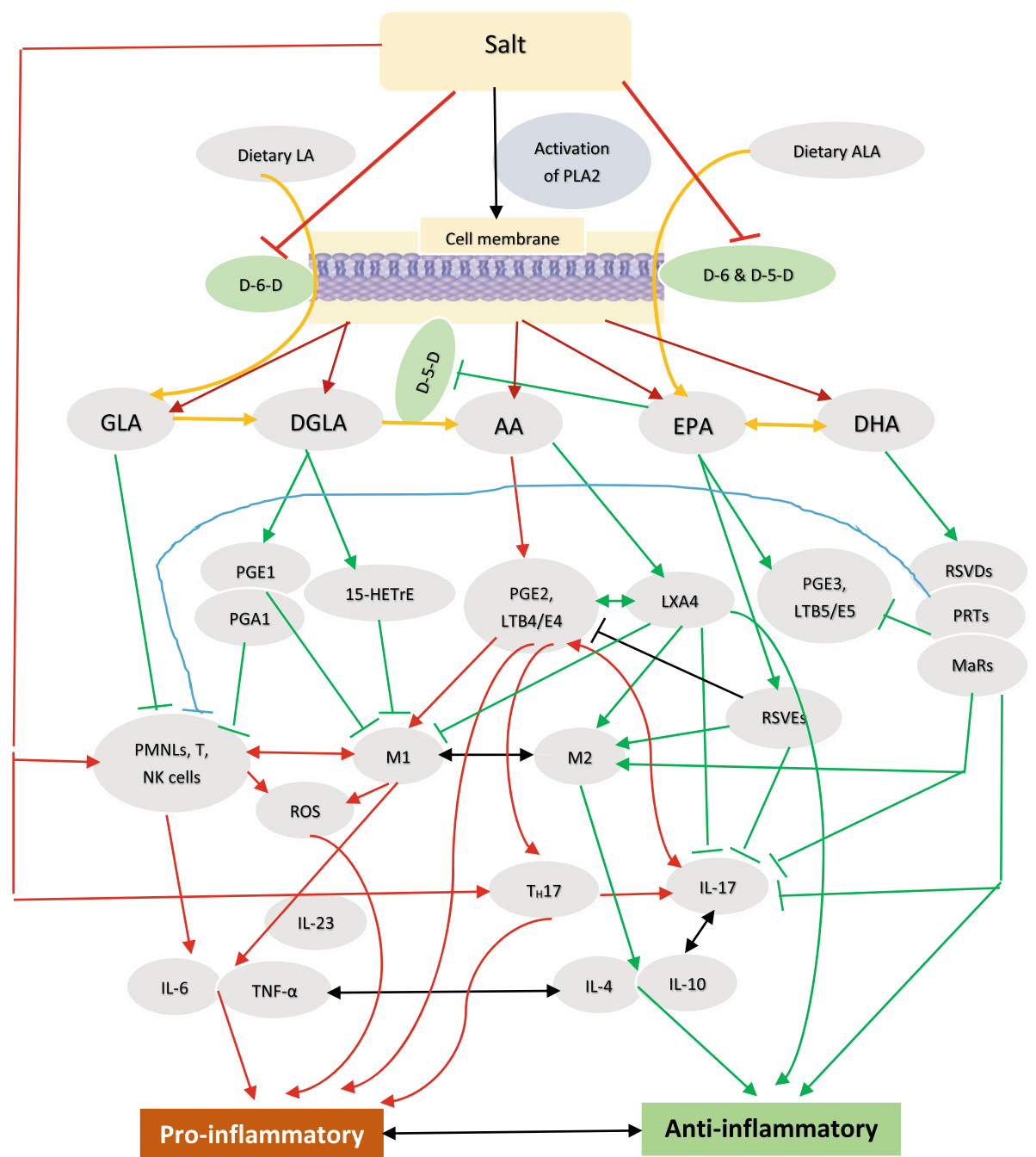

Fig. 1 Scheme showing EFA metabolism, interaction, and feedback regulation among immunocytes, cytokines, various bioactive lipids (BALs) and inflammation. 15-HETrE = 15-(S)-hydroxy-8,11,13-eicosatrienoic acid. M1 and M2 macrophages. Red lines indicate pro-inflammatory events; Green lines indicate anti-inflammatory events. For further details see the text

IL-2 and IL-17 production and thus, play a role in the pathobiology of HTN and T2DM.

\section{HTN as an immunological disorder}

The observation that salt enhances the production of IL17, a pro-inflammatory molecule, implies that HTN could be an immunological disorder. Increased salt intake induced elevation in plasma angiotensin-II levels [62] that, in turn is known to enhance IL-6 secretion and other pro-inflammatory molecules such as PGE2, NF-kB and IL-17 [24, 63-65, 78-81]. It was reported that the basal plasma levels of IL- 6 were higher in those with HTN compared to control. These results suggest that HTN is associated with pro-inflammatory status and angiotensin-II is a pro-inflammatory molecule.

Furthermore, angiotensin-II mediates induction of HTN by acting on $\mathrm{T}$ effector (Teff) cells. Under normal physiological conditions, $\mathrm{T}$ regulatory cells (Tregs) suppress Teff lymphocytes. In experimental animals, infusion of angiotensin-II ( $1 \mu \mathrm{g} / \mathrm{kg} /$ minute subcutaneous) for 14 days increased systolic blood pressure by more than $40 \mathrm{~mm} \mathrm{Hg}$, enhanced NADPH oxidase activity in aorta and heart by more than 1.5 fold, impaired acetylcholine vasodilatory action by $\sim 70 \%$ compared to control and enhanced vasculature stiffness and mesenteric artery vascular cell adhesion molecule expression by more than 2 fold and aortic macrophage and $\mathrm{T}$ cell infiltration, events that could be reversed by Treg cell adaptive transfer. Angiotensin-II induced decrease in Foxp $3^{+}$in renal cortex that was reverted to near normal by Treg cells transfer. These results suggest that angiotensininduced hypertension and other features are due to its pro-inflammatory action mediated by Teff cells and this can be reversed or prevented by Treg cells that have 
anti-inflammatory actions [117-125]. Thus, it is opined that angiotensin-II induced blood pressure elevation is due to its ability to induce oxidative stress, endothelial dysfunction, and activation of Teff cell function. It is known that Treg cells deficiency is associated with several autoimmune diseases [126]. This is further supported by the observation that IL-17 levels are increased in subjects with type $1 \mathrm{DM}$, lupus, and multiple sclerosis [127-130]. These results coupled with the reports that circulating levels of IgG and IgM antibodies are elevated in patients with essential and pregnancy-related hypertension that target G-protein coupled receptors and ion channels including AT1 receptors, $\alpha 1$-adrenoceptors, $\beta 1$-adrenoceptors, and Ltype voltage operated $\mathrm{Ca}(2+)$ channels imply that these antibodies play a critical role in the events that are important for regulating blood pressure including modulation of vascular tone, cardiac output, and/or $\mathrm{Na}(+$ )/water reabsorption in the kidneys [131]. Since normally there is a close interaction between $\mathrm{T}$ and $\mathrm{B}$ cells in the regulation of immune response, it is reasonable to suggest that both $\mathrm{T}$ and $\mathrm{B}$ cells have a regulatory role in the pathobiology of HTN and T2DM and other inflammatory diseases including type $1 \mathrm{DM}$. In this context, it is noteworthy that EFAs and their metabolites have a regulatory role in the generation and action of $\mathrm{T}$ and $\mathrm{B}$ cells [132-144] (see Figs. 2, 3 and 4). At this juncture, it is reasonable to argue that not all hypertensives have increased salt intake except those who have salt sensitive HTN. It is likely that in those who do not have salt sensitive HTN may have other abnormalities such as relatively decreased intake of potassium, magnesium and calcium and decreased formation of downstream metabolites of EFAs such as GLA, AA, EPA and DHA and lipoxins, resolvins protectins and maresins. These abnormalities may lead to increased formation of IL-17 secondary to the absence of negative feedback control exerted by potassium, magnesium, EFAs and their metabolites. This ultimately leads to enhanced generation of IL-17 by endothelial cells and various immunocytes leading to the onset of HTN [116, 145-149].

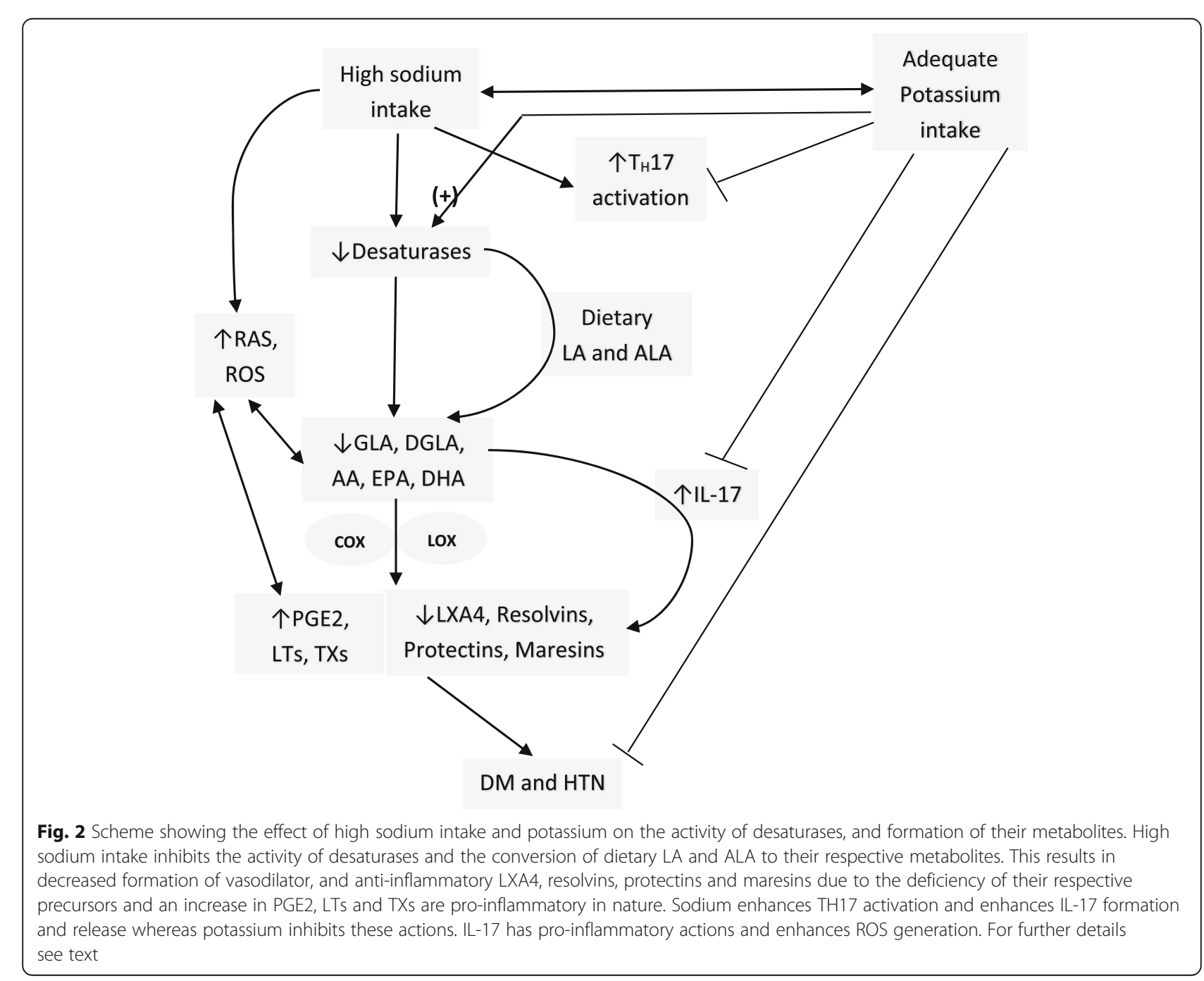




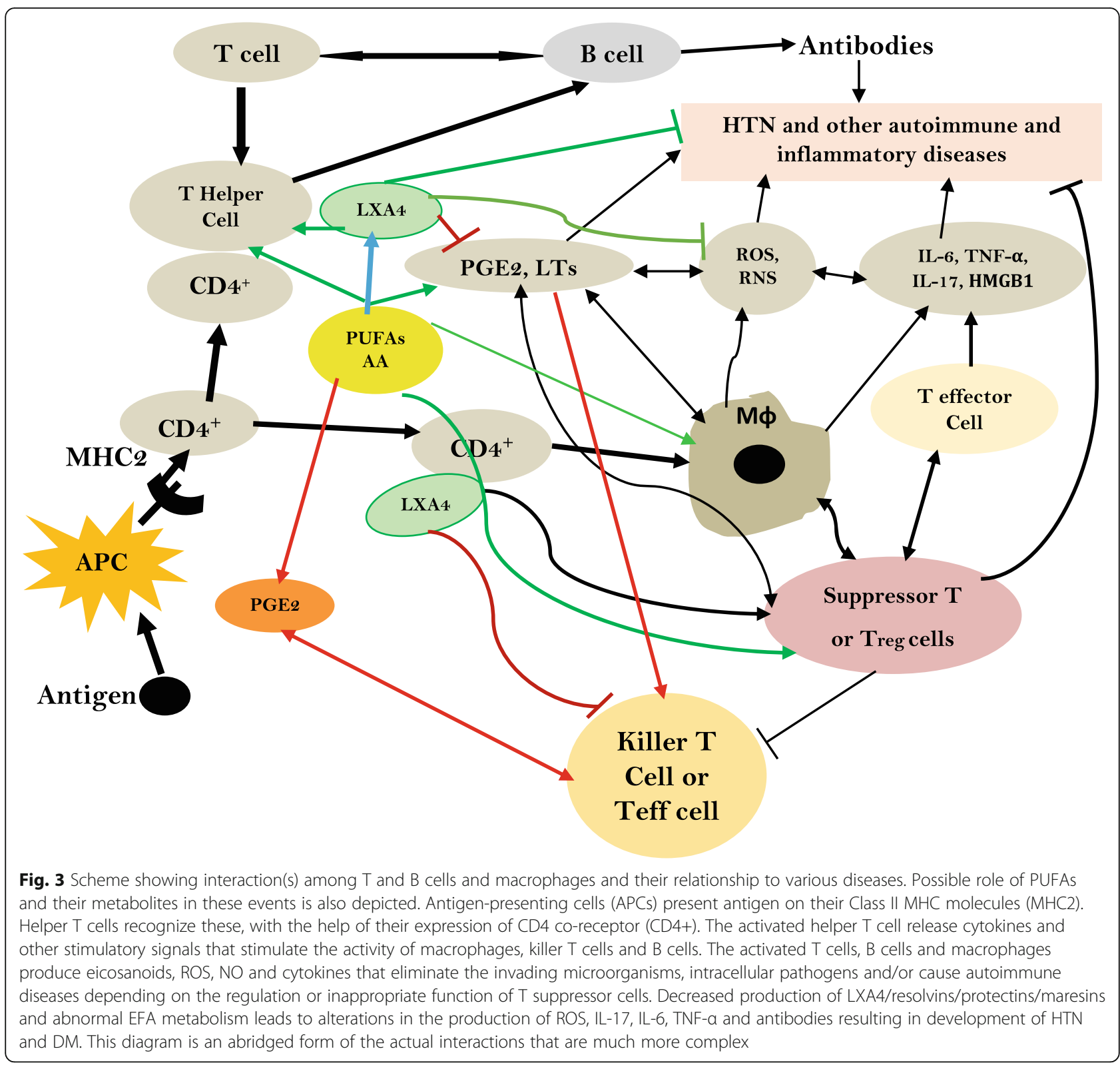

\section{EFAs in the pathobiology of HTN and T2DM}

Dietary EFAs: cis-linoleic acid (LA, 18:2 n-6) and alphalinolenic acid (ALA, 18:3 n-3) are essential for the survival of humans. EFAs are needed for integrity of skin, normal immune function, and inflammation. EFAs deficiency can result in death due to dehydration, desquamation of skin, poor wound healing, growth retardation, immunosuppression and increased infections, hepatic and splenic dysfunction and abnormal inflammation that eventually can lead to death. But EFAs deficiency is rare since they are present in almost all food that we consume. EFAs deficiency is common in those who are on total parenteral nutrition (when they do not receive enough EFAs in the parenteral fluids), suffer from longstanding and severe bowel disease, following massive bowel resection surgery, pancreatic surgery, and gastric bypass surgery and have significant cystic fibrosis [150153]. Due to the awareness of importance of EFAs in health, now a days all patients receive EFAs supplementation and so is rare. The significance of EFAs resides in the fact that they are essential for normal skin function and to prevent water loss through skin since they are important for skin integrity and for normal immune response. EFAs form an important constituent of cell membrane and regulate cell membrane fluidity [153]. In addition, EFAs are converted into their long-chain metabolites namely gamma-linolenic acid (GLA, 18:3 n-6), dihomo-GLA (DGLA, 20:3 n-6) and arachidonic acid (AA, 20:4 n-6) from LA and eicosapentaenoic acid (EPA, 20:5 n-3) and docosahexaenoic acid (DHA, 22:6 n-3) 


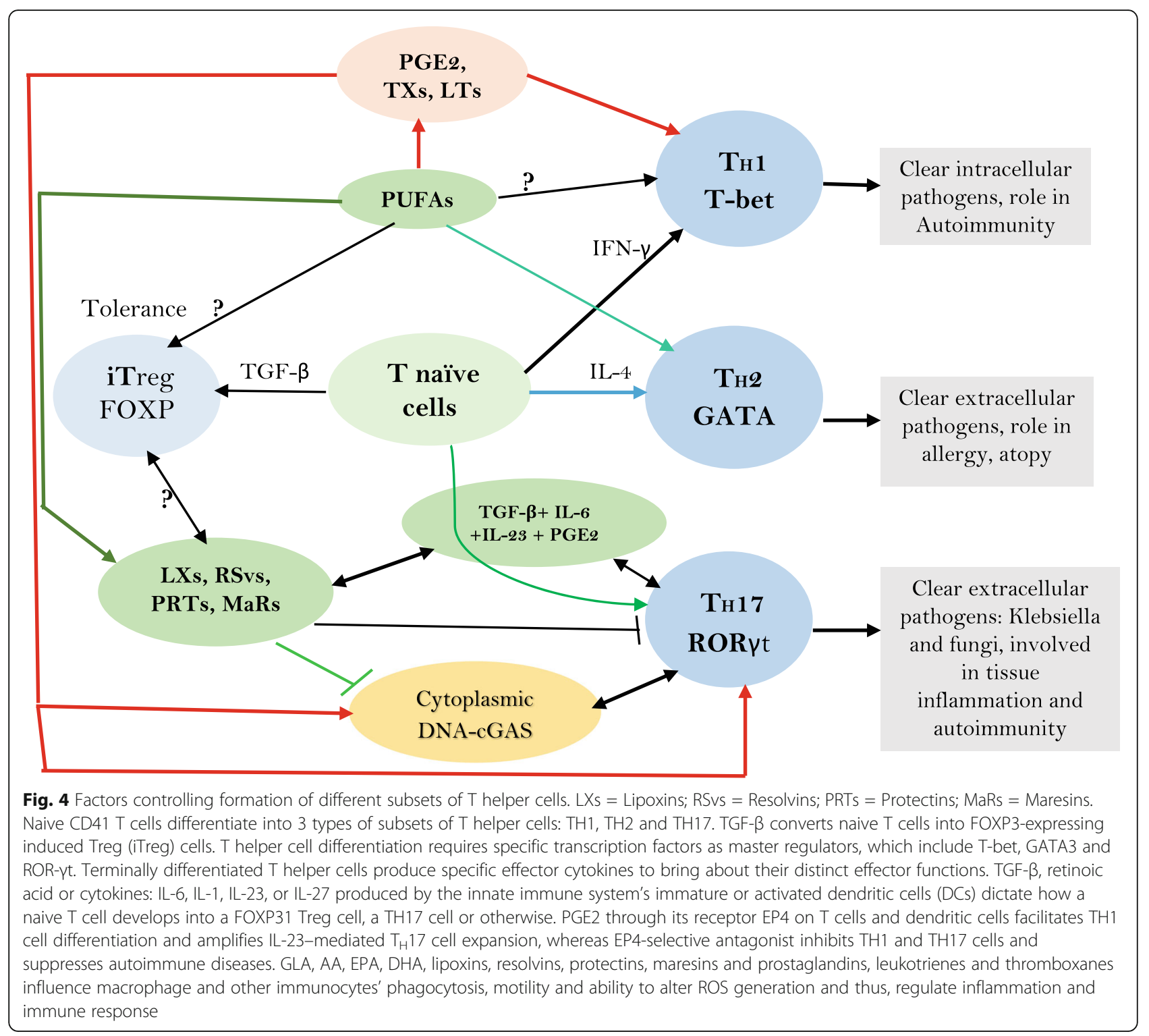

from ALA by the action of enzymes delta-6- and delta5-desaturases and elongases (see Fig. 3). DGLA is the precursor of 1 series prostaglandins (PGs), whereas AA is the precursor of 2 series PGs, thromboxanes (TXs) and 4 series leukotrienes (LTs). EPA is the precursor of 3 series PGs and TXS and 5 series LTs. PGs, TXs and LTs generally have pro-inflammatory actions but those formed from EPA are less pro-inflammatory compared to those formed from AA. In addition, PGE1 from DGLA, PGI2 and PGJ2 from AA have anti-inflammatory actions. AA is the precursor of lipoxin A4 (LXA4), a potent anti-inflammatory compound. EPA is the precursor of resolvins of $\mathrm{E}$ series, whereas resolvins of $\mathrm{D}$ series, protectins and maresins are derived form DHA. Resolvins, protectins and maresins are all potent antiinflammatory compounds. It is evident from this discussion that EFAs are the precursors of a variety of pro and anti-inflammatory compounds that play a significant role in inflammation, wound healing, immune response and protecting the body from various bacterial, viral, fungal, and parasitic infections [153]. It is note worthy that PGs, TXs, LTs, LXA4, resolvins, protectins and maresins modulate vascular tone, regulate insulins secretion, and have significant role in the modulation of actions of leukocytes, macrophages, monocytes, $\mathrm{T}$ cells and B cells [154-157]. In view of these actions, EFAs and their metabolites have a critical role in the regulation of blood pressure and pathobiology of both type 1 and type 2 diabetes mellitus [15, 93, 158-163]. One of the actions of EFAs and their metabolites include their ability to modulate secretion and action of cytokines, ROS generation and T cell function (see Fig. 2). 
EFAs and their metabolites regulate $T$ cells development and its relevance to HTN and T2DM

On exposure to different stimuli, naïve $\mathrm{T}$ cells get activated, form three distinct effector $\mathrm{TH}$ subsets: $\mathrm{TH} 1$ cells produce IFN- $\gamma ; \mathrm{TH} 2$ cells produce IL-4, IL-13 and IL25; the third subset of $\mathrm{TH}$ cells known as TH17 cells produce IL-17. TH17 cells also produce IL-21 and IL-22. TGF- $\beta$, IL-6, IL-21, IL-23, and IL- $1 \beta$ have a role in the formation of TH17 cells. High concentrations of TGF- $\beta$ inhibit IL-6-induced IL-22 expression, whereas a combination of TGF- $\beta$ and IL- 6 induce generation of IL-17 by TH17 cells. IL-22 production by TH17 cells need the co-operation of IL-23. Thus, IL-22 is the end point effector cytokine secreted by TH17 cells [164-171] (see Figs. 1, 2 and 3).

IL-17, a pro-inflammatory cytokine, is secreted by $\mathrm{T}$ helper 17 cell in response to stimulation by IL-23. IL-17 stimulates the induction of chemokines and thus, monocytes and neutrophils are recruited to the site of inflammation. IL-17 acts in conjunction with TNF and IL-1 and plays a critical role in autoimmune diseases and allergic responses. IL-17 enhances the production of IL-6, G-CSF, GM-CSF, IL- $1 \beta$, TGF- $\beta$, TNF- $\alpha$, chemokines (including IL-8, GRO- $\alpha$, and MCP-1), and PGE2 by macrophages and other cells [172]. TH17 is needed for protection against Gram-positive and Gram-negative organisms and fungi [172] (see Fig. 4).

TH17 development is regulated by the transcription factor, the orphan nuclear receptor ROR-ct and TGF- $\beta$ plus IL-6. Furthermore, Treg cells and TH17 cells have a reciprocal relationship between them. This is supported by the observation that IL-2, a growth factor for Treg cells, inhibits the generation of TH17 cells, whereas lack of IL-2 reduces the number of Treg cells and increases TH17 cells and leads to the development of inflammatory diseases that can be suppressed Treg cells. IL-4, IL25, IL-27 and IFN- $\gamma$ inhibit the expansion of TH17 cells [166-172].

But surprisingly antibodies against IL-17 are not effective against inflammatory bowel disease, an autoimmune disease. In contrast, targeting IL-23 is effective [171]. PUFAs (especially EPA/DHA), lipoxins, resolvins, protectins and maresins inhibit IL-23 and IL-17 and hence are expected to prevent salt and HFD and carbohydrate-induced HTN and T2DM (see Fig. 4).

Several studies revealed that EFAs and their metabolites can regulate blood pressure and prevent development of HTN, at least, in part by restoring IL-17 and Treg balance, decreasing the formation of angiotensin-II and suppressing the expression of angiotensin-II receptors [141, 173-181]. We showed that GLA, DGLA, AA, EPA and DHA can prevent the development of both type 1 and type $2 \mathrm{DM}$ by alloxan and streptozotocin in experimental animals [158, 160, 163, 182]. Of all the fatty acids tested, AA was found to be the most potent in preventing type 1 and type $2 \mathrm{DM}$ due to its conversion to LXA4 [93]. It was found that resolvins and protectins also have anti-diabetic actions [183-185].

PGE2, derived from AA, induces the expression of IL23R in naïve $\mathrm{CD} 4^{+} \mathrm{T}$ cells. TXA4, a pro-inflammatory molecule derived from AA, also facilitates IL-17A production from ${\mathrm{V} \gamma 4^{+}}^{+} \delta \mathrm{T}$ cells [186-193]. Lipoxins, resolvins, protectins and maresins suppress IL-17 and IL-23 production, whereas PGE2 and TXA4 have opposite actions [186-193]. But, in an occasional instance, PGE2 suppresses the production of IL-23 and IL-12 and thus bring about its anti-inflammatory action [194]. But, in general, PGE2 and LTs, enhance the production of IL-17 and IL-23, whereas lipoxins, resolvins, protectins and maresins suppress their production [186-193] (see Figs. $1,2,3$ and 4).

\section{Conclusions and therapeutic implications}

It is evident from the preceding discussion that increased salt intake (and perhaps, in a similar fashioncarbohydrate/high fat diet or energy dense food) results in an: (i) increase in IL-17 production; (ii) decrease in the activity of desaturases leading to low levels of GLA, DGLA, AA, EPA and DHA and their anti-inflammatory, vasodilator, and platelet anti-aggregator metabolites LXA4, resolvins, protectins and maresins that have the ability to suppress IL-16, IL-6, IL-17 and TNF- $\alpha$ production; (iii) increase in PGE2, LTs, TXA2 production that have pro-inflammatory action [195, 196]; (iv) increase in the production of angiotensin-II that is proinflammatory in nature-events that facilitate the occurrence of HTN and T2DM. We observed that PUFAs can suppress the activity of ACE (angiotensin converting enzyme) [197] and thus, inhibit the formation of angiotensin-II, a pro-inflammatory and IL-17 formation stimulatory molecule. In addition, nitric oxide is a potent suppressor of ACE activity [197] and antagonizes the pro-inflammatory and vasoconstrictor action of angiotensin-II. PUFAs and their metabolites especially, PGE1, PGI2, LXA4, resolvins, protectins and maresins augment the production of NO [198-201] and thus, are of benefit in the prevention of HTN and DM. Despite the evidence presented above, it is not without controversy. For instance, it was reported that high-salt intake induces severe hypertension in WBN/Kob diabetic fatty (WBKDF) rats, whereas plasma glucose levels were significantly increased in WBKDF-NS (normal salt) but not in WBKDF-HS (high salt) rats. Even HOMA-IR (insulin resistance) in WBKDF-HS was significantly lower compared with that in WBKDF-NS that coincided with an increase in plasma adiponectin level in WBKDF-HS group. This paradoxical response shown by WBKDF-HS group to high salt supplementation in the form of 
reduced hyperglycemia and insulin resistance in WBKDF rats has been attributed to increased plasma levels of adiponectin [202]. In contrast to this, WBKDF-HFD (high fat diet) and WBKDF-FRD (fructose rich diet) rats exhibited aggravated obesity and dyslipidemia compared with WBKDF rats fed standard diet (STD). Paradoxically, hyperglycemia developed in WBKDF-STD rats was significantly inhibited in WBKDF-FRD rats, but not in WBKDF-HFD rats [203]. These results suggest that the response of WBKDF rats to high salt intake and high fat diet depends on other homeostatic mechanisms such as adiponectin and secretion of $\mathrm{NO}$, and response of the autonomic nervous system (including secretion of adrenaline and noradrenaline and acetylcholine). This argument is supported by the observation that WBKDF rats when fed with high salt not only had significant elevation of systolic blood pressure (SBP) but also showed enhanced phenylephrine-induced contractions of isolated thoracic aortic rings significantly reduced relaxation to acetylcholine- and nitroprusside and higher plasma concentrations of 8-iso-prostaglandin $\mathrm{F}_{2 \alpha}$ (a metabolite of PGI2, a vasodilator, platelet anti-aggregator and antiinflammatory molecule) [204]. The reduced responses to phenylephrine, acetylcholine and nitroprusside could be attributed to higher constitutional production of $\mathrm{NO}$ and PGI2 in WBKDF rats that is exaggerated by high salt and high fat diet. This is supported by the observation that NO can prevent hyperglycemia [205, 206]. It is noteworthy that adiponectin enhances eNO generation [207, 208] and augments insulin action [209, 210] explaining why diabetes mellitus is ameliorated in WBKDF-HS group.

Sodium-glucose cotransporter 2 inhibitors (SGLT2i) are hypoglycemic drugs that target SGLT2, the major glucose transporter in the kidney responsible for about 90 percent of glucose reabsorption from primary urine [8]. SGLT2i reduce glycosylated hemoglobin, body weight, blood pressure, plasma volume, and improve cardiac energy metabolism. The beneficial actions of SGLT2i are due to their ability to inhibit vascular inflammation, reduce oxidative stress, reverse endothelial dysfunction, reduce foam cell formation and prevent platelet activation [211], which are all pro-inflammatory events. It is interesting to note that SGLT2i empagliflozin acts via AMPK/mTOR pathway to enhance autophagy of hepatic macrophages and thus, prevents NAFLDrelated liver injury. Furthermore, empagliflozin inhibits IL-17/IL-23 axis and thus, mediates its antiinflammatory actions [212, 213]. This lends support to the concept that both salt and glucose bring about their pro-inflammatory actions by enhancing the production of IL-17.

In this context, it is noteworthy that regulatory $\mathrm{T}$ cells (Tregs) express FOXP3, which is needed for natural
Tregs (nTregs) along with TGF $\beta$ and retinoic acid for induced Tregs (iTreg). Interestingly, the signature transcription factor for Th17 cells, RORyt, is induced by TGF $\beta$, thus linking the differentiation of the Treg and TH17 lineages. FOXP3 can inhibit ROR $\gamma$ t function and drive Treg differentiation. However, when the cell receives a signal from IL-6, FOXP3 function is inhibited and the differentiation pathway is induced. Thus, the balance between FOXP3 and RORyt function determines $\mathrm{CD} 4 \mathrm{~T}$ cell fate and the type of immune response that will be generated [214]. It is important to note that PGE2, LTs, and other bioactive lipids regulate the expression of FOXP3 and thus, regulate/control the generation of TH17 cells, their ability to secrete IL-17; Tregs and thus, modulate inflammatory process $[179,181$, 215-232] (see Figures 3 and 4).

Based on these results, it is suggested that in addition to reducing the intake of salt, carbohydrate and energy dense foods, it is worthwhile to supplement various EFAs, especially AA/EPA/DHA, their co-factors that are essential for the normal physiological action of desaturases such as vitamin $\mathrm{C}$, folic acid, B1, B6, B12, zinc, and magnesium to prevent the development of HTN and T2DM and to inhibit their progression if they are already present.

\section{Abbreviations \\ BALs: Bioactive lipids (these are LA, ALA, GLA, DGLA, AA, EPA, DHA, lipoxins, resolvins, protectins, maresins, prostaglandins, leukotrienes, thromboxanes as defined in the present discussion); EFAs: Essential fatty acids; ALA: Alpha- linolenic acid; AA: Arachidonic acid; CVD: Cardiovascular disease; CGAS- STING: cyclic GMP-AMP synthase linked to stimulator of interferon genes; COX: Cyclo-oxygenase; DGLA: Dihomo-GLA; DHA: Docosahexaenoic acid; EPA: Eicosapentaenoic acid; GLA: Gamma-linolenic acid; GM- CSF: Granulocyte-macrophage colony stimulating factor; HFD: High fat diet; HTN: Hypertension; IL: Interleukin; IFN: Interferon; LA: Linoleic acid; LXA4: Lipoxin A4; LTs: Leukotrienes; LOX: Lipoxygenase; MnSOD: Manganese superoxide dismutase; NADPH: Nicotinamide adenine dinucleotide phosphate; NO: Nitric oxide; PLA2: Phospholipase A2; PNS: Parasympathetic nervous system; PGs: Prostaglandins; ROS: Reactive oxygen species; SNS: Sympathetic nervous system; STZ: Streptozotocin; TXs: Thromboxanes; T2DM: Type 2 diabetes mellitus; TNF-a: Tumor necrosis factor-a; $T_{H}$ cells: $T$ helper cells; Teff cells: T effector cells}

\section{Acknowledgements}

Not applicable

\begin{abstract}
Author's contributions manuscript.

Funding

Nil

Availability of data and materials Not applicable
\end{abstract}

UND proposed and developed the idea, collected the data, analyzed the data. and prepared the manuscript. The author read and approved the final

\section{Declarations}

Ethics approval and consent to participate Not applicable 


\section{Consent for publication}

All the authors have approved and gave consent for publication

\section{Competing interests}

The authors declare that they have no competing interests.

\section{Received: 9 January 2021 Accepted: 14 July 2021}

Published online: 01 August 2021

\section{References}

1. Das UN. Risk of type 2 diabetes mellitus in those with hypertension. Eur Heart J. 2008;29:952-3.

2. Das UN. Minerals, trace elements, and vitamins interact with essential fatty acids and prostaglandins to prevent hypertension, thrombosis, hypercholesterolaemia and atherosclerosis and their attendant complications. IRCS Med Sci. 1985;13:684-7.

3. Olver TD, Grunewald ZI, Jurrissen TJ, MacPherson REK, LeBlanc PJ, Schnurbusch TR, et al. Microvascular insulin resistance in skeletal muscle and brain occurs early in the development of juvenile obesity in pigs. Am J Phys Regul Integr Comp Phys. 2018;314:R252-64.

4. Gierach MA, Junik R. Insulin resistance in metabolic syndrome depending on the occurrence of its components. Endokrynol Pol. 2021. https://doi. org/10.5603/EP.a2021.0037. Epub ahead of print

5. Naryzhnaya NV, Koshelskaya OA, Kologrivova IV, Kharitonova OA Evtushenko W, Boshchenko AA. Hypertrophy and Insulin Resistance of Epicardial Adipose Tissue Adipocytes: Association with the Coronary Artery Disease Severity. Biomedicines. 2021;9(1):64. https://doi.org/10.3390/ biomedicines 9010064

6. Bosy-Westphal A, Onur S, Geisler C, Wolf A, Korth O, Pfeuffer M, et al. Common familial influences on clustering of metabolic syndrome traits with central obesity and insulin resistance: the Kiel obesity prevention study. Int J Obes. 2007;31:784-90.

7. Tjokroprawiro A. New approach in the treatment of T2DM and metabolic syndrome (focus on a novel insulin sensitizer). Acta Med Indones. 2006;38: 160-6.

8. Majumdar UB, Hunt C, Doupe P, Baum AJ, Heller DJ, Levine EL, et al. Multiple chronic conditions at a major urban health system: a retrospective cross-sectional analysis of frequencies, costs and comorbidity patterns. BMJ Open. 2019:9:e029340

9. $\quad$ Fang Y, Mu JJ, He LC, Wang SC, Liu ZQ. Salt loading on plasma asymmetrical dimethylarginine and the protective role of potassium supplement in normotensive salt-sensitive Asians. Hypertension. 2006;48: 724-9.

10. Petrie JR, Guzik TJ, Touyz RM. Diabetes, hypertension, and cardiovascular disease: clinical insights and vascular mechanisms. Can J Cardiol. 2018;34: 575-84.

11. Das UN. Genes, genetic polymorphism, diet, soluble mediators, and their role in the pathobiology of type 2 diabetes mellitus and hypertension. Am J Hypertens. 2021;34:583-6.

12. Han JQ, Liu CL, Wang ZY, Liu L, Cheng L, Fan YD. Anti-inflammatory properties of lipoxin A4 protect against diabetes mellitus complicated by focal cerebral ischemia/reperfusion injury. Neural Regen Res. 2016;11:63640.

13. Börgeson E, McGillicuddy FC, Harford KA, Corrigan N, Higgins DF, Maderna $P$, et al. Lipoxin A4 attenuates adipose inflammation. FASEB J. 2012;26:428794.

14. Dahik VD, Frisdal E, Le Goff W. Rewiring of Lipid Metabolism in Adipose Tissue Macrophages in Obesity: Impact on Insulin Resistance and Type 2 Diabetes. Int J Mol Sci. 2020:21:5505.

15. Bellenger J, Bellenger S, Bataille A, Massey KA, Nicolaou A, Rialland M, et al. High pancreatic n-3 fatty acids prevent STZ-induced diabetes in fat-1 mice: inflammatory pathway inhibition. Diabetes. 2011;60:1090-9.

16. Gromovsky AD, Schugar RC, Brown AL, Helsley RN, Burrows AC, Ferguson D, et al. $\Delta-5$ Fatty Acid Desaturase FADS1 Impacts Metabolic Disease by Balancing Proinflammatory and Proresolving Lipid Mediators. Arterioscler Thromb Vasc Biol. 2018:38:218-31.

17. Sansbury BE, Hill BG. Regulation of obesity and insulin resistance by nitric oxide. Free Radic Biol Med. 2014;73:383-99.

18. Kleinewietfeld M, Manzel A, Titze J, Kvakan H, Yosef N, Linker RA, et al. Sodium chloride drives autoimmune disease by the induction of pathogenic TH17 cells. Nature. 2013;496:518-22.
19. Wen W, Wan Z, Ren K, Zhou D, Gao Q, Wu Y, et al. Potassium supplementation inhibits IL-17A production induced by salt loading in human T lymphocytes via p38/MAPK-SGK1 pathway. Exp Mol Pathol. 2016; 100:370-7.

20. Abdel-Moneim A, Bakery HH, Allam G. The potential pathogenic role of IL17/Th17 cells in both type 1 and type 2 diabetes mellitus. Biomed Pharmacother. 2018;101:287-92.

21. Fatima N, Faisal SM, Zubair S, Siddiqui SS, Moin S, Owais M. Emerging role of Interleukins IL-23/IL-17 axis and biochemical markers in the pathogenesis of Type 2 Diabetes: Association with age and gender in human subjects. Int J Biol Macromol. 2017:105(Pt 1):1279-88.

22. Zareian P, Mirzaii DI. Serum Interleukin 17 in Type 2 Diabetes Mellitus. J Arch Mil Med. 2014:2(4):e24689.

23. Silver AE, Beske SD, Christou DD, Donato AJ, Moreau KL, Eskurza I, et al. Overweight and obese humans demonstrate increased vascular endothelial $\mathrm{NAD}(\mathrm{P}) \mathrm{H}$ oxidase-p47(phox) expression and evidence of endothelia oxidative stress. Circulation. 2007;115:627-37.

24. Pontremoli S, Salamino F, Sparatore B, De Tullio R, Patrone M, Tizianello A, et al. Enhanced activation of the respiratory burst oxidase in neutrophils from hypertensive patients. Biochem Biophys Res Commun. 1989;158:96672.

25. Sahoo S, Meijles DN, Pagano PJ. NADPH oxidases: key modulators in aging and age-related cardiovascular diseases? Clin Sci (Lond). 2016;130: 317-35.

26. Griendling KK, Sorescu D, Ushio-Fukai M. NAD(P)H oxidase: role in cardiovascular biology and disease. Circ Res. 2000;86:494-501.

27. Gaspar RS, Ferreira PM, Mitchell JL, Pula G, Gibbins JM. Platelet-derived extracellular vesicles express NADPH oxidase-1 (Nox-1), generate superoxide and modulate platelet function. Free Radic Biol Med. 2021;165:395-400.

28. Akbar H, Duan X, Piatt R, Saleem S, Davis AK, Tandon NN, et al. Small molecule targeting the Rac1-NOX2 interaction prevents collagen-related peptide and thrombin-induced reactive oxygen species generation and platelet activation. J Thromb Haemost. 2018;16:2083-96.

29. Kuwano Y, Tominaga K, Kawahara T, Sasaki H, Takeo K, Nishida K, et al. Tumor necrosis factor alpha activates transcription of the NADPH oxidase organizer 1 (NOXO1) gene and upregulates superoxide production in colon epithelial cells. Free Radic Biol Med. 2008;45:1642-52.

30. Awasthi $D$, Nagarkoti $S$, Kumar A, Dubey $M$, Singh AK, Pathak $P$, et al. Oxidized LDL induced extracellular trap formation in human neutrophils via TLR-PKC-IRAK-MAPK and NADPH-oxidase activation. Free Radic Biol Med. 2016:93:190-203.

31. Yang CM, Hsieh HL, Yu PH, Lin CC, Liu SW. IL-1ß Induces MMP-9-Dependent Brain Astrocytic Migration via Transactivation of PDGF Receptor/NADPH Oxidase 2-Derived Reactive Oxygen Species Signals. Mol Neurobiol. 2015;52: 303-17.

32. Moe KT, Khairunnisa K, Yin NO, Chin-Dusting J, Wong P, Wong MC. Tumo necrosis factor-a-induced nuclear factor-kappaB activation in human cardiomyocytes is mediated by NADPH oxidase. J Physiol Biochem. 2014;70: 769-79.

33. Bonizzi G, Piette J, Merville MP, Bours V. Cell type-specific role for reactive oxygen species in nuclear factor-kappaB activation by interleukin-1. Biochem Pharmacol. 2000;59:7-11.

34. Bouzidi F, Doussiere J. Binding of arachidonic acid to myeloid-related proteins (S100A8/A9) enhances phagocytic NADPH oxidase activation. Biochem Biophys Res Commun. 2004;325:1060-5.

35. Cherny W, Henderson LM, Xu W, Thomas LL, DeCoursey TE. Activation of $\mathrm{NADPH}$ oxidase-related proton and electron currents in human eosinophils by arachidonic acid. J Physiol. 2001;535(Pt 3):783-94.

36. Kumar KV, Das UN. Are free radicals involved in the pathobiology of human essential hypertension? Free Radic Res Commun. 1993;19:59-66.

37. Yamamoto N, Otsuka Y, Kushiro T, Kajiwara N. Role of superoxide anion on onset and maintenance of hypertension in spontaneously hypertensive rats. Nihon Jinzo Gakkai Shi. 1992;34:717-23.

38. Cuzzocrea S, Mazzon E, Dugo L, Di Paola R, Caputi AP, Salvemini D. Superoxide: a key player in hypertension. FASEB J. 2004;18:94-101.

39. McIntyre M, Bohr DF, Dominiczak AF. Endothelial function in hypertension: the role of superoxide anion. Hypertension. 1999;34(4 Pt 1):539-45.

40. Grunfeld S, Hamilton CA, Mesaros S, McClain SW, Dominiczak AF, Bohr DF, et al. Role of superoxide in the depressed nitric oxide production by the endothelium of genetically hypertensive rats. Hypertension. 1995;26(6 Pt 1): 854-7. 
41. Cohen RA, Tong X. Vascular oxidative stress: the common link in hypertensive and diabetic vascular disease. J Cardiovasc Pharmacol. 2010;55: 308-16

42. Guzik TJ, Mussa S, Gastaldi D, Sadowski J, Ratnatunga C, Pillai R, et al. Mechanisms of increased vascular superoxide production in human diabetes mellitus: role of $\mathrm{NAD}(\mathrm{P}) \mathrm{H}$ oxidase and endothelial nitric oxide synthase. Circulation. 2002;105:1656-62.

43. Weidig P, McMaster D, Bayraktutan U. High glucose mediates pro-oxidant and antioxidant enzyme activities in coronary endothelial cells. Diabetes Obes Metab. 2004;6:432-41.

44. Zanetti M, Zwacka R, Engelhardt J, Katusic Z, O'Brien T. Superoxide anions and endothelial cell proliferation in normoglycemia and hyperglycemia. Arterioscler Thromb Vasc Biol. 2001;21:195-200.

45. Zhang C, Yang J, Jacobs JD, Jennings LK. Interaction of myeloperoxidase with vascular $\mathrm{NAD}(\mathrm{P}) \mathrm{H}$ oxidase-derived reactive oxygen species in vasculature: implications for vascular diseases. Am J Physiol Heart Circ Physiol. 2003;285:H2563-72.

46. Zhang C, Yang J, Jennings LK. Leukocyte-derived myeloperoxidase amplifies high-glucose--induced endothelial dysfunction through interaction with high-glucose--stimulated, vascular non--leukocyte-derived reactive oxygen species. Diabetes. 2004;53:2950-9.

47. Pias EK, Ekshyyan OY, Rhoads CA, Fuseler J, Harrison L, Aw TY. Differential effects of superoxide dismutase isoform expression on hydroperoxideinduced apoptosis in PC-12 cells. J Biol Chem. 2003;278:13294-301.

48. Becuwe P, Ennen M, Klotz R, Barbieux C, Grandemange S. Manganese superoxide dismutase in breast cancer: from molecular mechanisms of gene regulation to biological and clinical significance. Free Radic Biol Med. 2014;77:139-51.

49. Lastra G, Syed S, Kurukulasuriya LR, Manrique C, Sowers JR. Type 2 diabetes mellitus and hypertension: an update. Endocrinol Metab Clin N Am. 2014; 43:103-22.

50. Hu G, Jousilahti P, Tuomilehto J. Joint effects of history of hypertension at baseline and Type 2 diabetes at baseline and during follow-up on the risk of coronary heart disease. Eur Heart J. 2007;28:3059-66.

51. Emerging Risk Factors Collaboration, Sarwar N, Gao P, Seshasai SR, Gobin R, Kaptoge S, et al. Emerging Risk Factors Collaboration. Diabetes mellitus, fasting blood glucose concentration, and risk of vascular disease: a collaborative meta-analysis of 102 prospective studies. Lancet. 2010;375: 2215-22.

52. Conen D, Ridker PM, Mora S, Buring JE, Glynn RJ. Blood pressure and risk of developing type 2 diabetes mellitus: The Women's Health Study. Eur Heart J. 2007;28:2937-43.

53. Ridker PM, Buring JE, Cook NR, Rifai N. C-reactive protein, the metabolic syndrome, and risk of incident cardiovascular events: an 8-year follow-up of 14719 initially healthy American women. Circulation. 2003;107:391-7.

54. Harwani SC, Chapleau MW, Legge KL, Ballas ZK, Abboud FM. Neurohormonal modulation of the innate immune system is proinflammatory in the prehypertensive spontaneously hypertensive rat, a genetic model of essential hypertension. Circ Res. 2012;111:1190-7.

55. Singh MV, Chapleau MW, Harwani SC, Abboud FM. The immune system and hypertension. Immunol Res. 2014;59(1-3):243-53.

56. De Ciuceis C, Rossini C, La Boria E, Porteri E, Petroboni B, Gavazzi A, et al. Immune mechanisms in hypertension. High Blood Press Cardiovasc Prev. 2014;21:227-34

57. Darakjian L, Deodhar M, Turgeon J, Michaud V. Chronic Inflammatory Status Observed in Patients with Type 2 Diabetes Induces Modulation of Cytochrome P450 Expression and Activity. Int J Mol Sci. 2021;22:4967.

58. Hameed I, Masoodi SR, Mir SA, Nabi M, Ghazanfar K, Ganai BA. Type 2 diabetes mellitus: From a metabolic disorder to an inflammatory condition. World J Diabetes. 2015;6:598-612

59. Hoffmann IS, Cubeddu LX. Increased blood pressure reactivity to dietary salt in patients with the metabolic syndrome. J Hum Hypertens. 2007;21:438-44.

60. Hoffmann IS, Cubeddu LX. Salt and the metabolic syndrome. Nutr Metab Cardiovasc Dis. 2009;19:123-8.

61. Koo JR, Ni Z, Oviesi F, Vaziri ND. Antioxidant therapy potentiates antihypertensive action of insulin in diabetic rats. Clin Exp Hypertens. 2002; 24:333-44.

62. Majid DS, Prieto MC, Navar LG. Salt-Sensitive Hypertension: Perspectives on Intrarenal Mechanisms. Curr Hypertens Rev. 2015;11:38-48.

63. Mattson DL. Infiltrating immune cells in the kidney in salt-sensitive hypertension and renal injury. Am J Physiol Ren Physiol. 2014;307:F499-508.
64. Campese VM, Romoff MS, Levitan D, Saglikes Y, Friedler RM, Massry SG. Abnormal relationship between sodium intake and sympathetic nervous system activity in salt-sensitive patients with essential hypertension. Kidney Int. 1982:21:371-8.

65. Flierl MA, Rittirsch D, Nadeau BA, Chen AJ, Sarma JV, Zetoune FS, et al. Phagocyte derived catecholamines enhance acute inflammatory injury. Nature. 2007:449:721-5.

66. Borovikova LV, Ivanova S, Zhang M, Yang H, Botchkina Gl, Watkins LR, et al. Vagus nerve stimulation attenuates the systemic inflammatory response to endotoxin. Nature. 2000;405(6785):458-62

67. Patel H, Mclntire J, Ryan S, Dunah A, Loring R. Anti-inflammatory effects of astroglial a7 nicotinic 19 acetylcholine receptors are mediated by inhibition of the NF-KB pathway and activation of the 20 Nrf2 pathway. J Neuroinflammation. 2017;14:192.

68. Soares V, Silveira de Avelar I, Espíndola Mota Venâncio P, Pires-Oliveira DAA, de Almeida Silva PH, Rodrigues Borges A, et al. Acute Changes in Interleukin-6 Level During Four Days of Long-Distance Walking. J Inflamm Res. 2020;13:871-8.

69. Das UN. Anti-inflammatory nature of exercise. Nutrition. 2004;20:323-6.

70. Teixeira de Lemos E, Reis F, Baptista S, Pinto R, Sepodes B, Vala H, et al. Exercise training decreases proinflammatory profile in Zucker diabetic (type 2) fatty rats. Nutrition. 2009;25:330-9.

71. Gupt AM, Kumar M, Sharma RK, Misra R, Gupt A. Effect of Moderate Aerobic Exercise Training on Autonomic Functions and its Correlation with the Antioxidant Status. Indian J Physiol Pharmacol. 2015;59:162-9.

72. Fischer CP. Interleukin-6 in acute exercise and training: what is the biological relevance? Exerc Immunol Rev. 2006;12:6-33.

73. Sellami M, Bragazzi NL, Aboghaba B, Elrayess MA. The Impact of Acute and Chronic Exercise on Immunoglobulins and Cytokines in Elderly: Insights From a Critical Review of the Literature. Front Immunol. 2021; 12:631873.

74. Suzuki K, Nakaji S, Yamada M, Totsuka M, Sato K, Sugawara K. Systemic inflammatory response to exhaustive exercise. Cytokine kinetics Exerc Immunol Rev. 2002:8:6-48.

75. Leite-Almeida L, Morato M, Cosme D, Afonso J, Areias JC, Guerra A, et al. Impact of physical activity on redox status and nitric oxide bioavailability in nonoverweight and overweight/obese prepubertal children. Free Radic Biol Med. 2021;163:116-24.

76. Clarke J. Exercise exerts anti-inflammatory effects on muscle via the JAKSTAT pathway. Nat Rev Rheumatol. 2021;17:127.

77. Hanson ED, Bates LC, Bartlett DB, Campbell JP. Does exercise attenuate ageand disease-associated dysfunction in unconventional T cells? Shining a light on overlooked cells in exercise immunology. Eur J Appl Physiol. 2021. https://doi.org/10.1007/s00421-021-04679-4. Epub ahead of print.

78. Das UN. Is angiotensin II an endogenous pro-inflammatory molecule? Med Sci Monit. 2005;11:RA155-62.

79. Ebrahimian T, Li MW, Lemarié CA, Simeone SM, Pagano PJ, Gaestel M, et al. Mitogen-activated protein kinase-activated protein kinase 2 in angiotensin Il-induced inflammation and hypertension: regulation of oxidative stress. Hypertension. 2011;57:245-54.

80. Pfister SL, Nithipatikom K, Campbell WB. Role of superoxide and thromboxane receptors in acute angiotensin Il-induced vasoconstriction of rabbit vessels. Am J Physiol Heart Circ Physiol. 2011;300:H2064-71.

81. Luo Z, Teerlink T, Griendling K, Aslam S, Welch WJ, Wilcox CS. Angiotensin II and NADPH oxidase increase ADMA in vascular smooth muscle cells. Hypertension. 2010;56:498-504

82. Boegehold MA. The effect of high salt intake on endothelial function: reduced vascular nitric oxide in the absence of hypertension. J Vasc Res. 2013:50:458-67.

83. Sanders PW. Vascular consequences of dietary salt intake. Am J Physiol Ren Physiol. 2009;297:F237-43.

84. Nurkiewicz TR, Boegehold MA. High salt intake reduces endotheliumdependent dilation of mouse arterioles via superoxide anion generated from nitric oxide synthase. Am J Phys Regul Integr Comp Phys. 2007;292: R1550-6.

85. Lenda DM, Sauls BA, Boegehold MA. Reactive oxygen species may contribute to reduced endothelium-dependent dilation in rats fed high salt. Am J Physiol Heart Circ Physiol. 2000;279:H7-H14.

86. Lenda DM, Boegehold MA. Effect of a high salt diet on microvascular antioxidant enzymes. J Vasc Res. 2002:39:41-50. 
87. Chandy KG, Norton RS. Immunology: Channelling potassium to fight cancer. Nature. 2016;537:497-9.

88. Eil R, Vodnala SK, Clever D, Klebanoff CA, Sukumar M, Pan JH, et al. lonic immune suppression within the tumour microenvironment limits $T$ cell effector function. Nature. 2016;537:539-43.

89. Mahfouz MM, Kummerow FA. Effect of magnesium deficiency on delta 6 desaturase activity and fatty acid composition of rat liver microsomes. Lipids. 1989;24:727-32.

90. Mahfouz MM, Smith TL, Kummerow FA. Changes of linoleic acid metabolism and cellular phospholipid fatty acid composition in LLC-PK cells cultured at low magnesium concentrations. Biochim Biophys Acta. 1989;1006:70-4.

91. Das UN. Interaction(s) of polyunsaturated fatty acids with dietary protein and its relationship to the pathogenesis of hypertension. Am J Hypertens. 2010;23:111-2.

92. Das UN. Essential fatty acids and their metabolites in the context of hypertension. Hypertens Res. 2010;33:782-5.

93. Naveen KVG, Naidu VGM, Das UN. Arachidonic acid and lipoxin A4 attenuate streptozotocin-induced cytotoxicity to RIN5F cells in vitro and type 1 and type 2 diabetes mellitus in vivo. Nutrition. 2017;35:61-80,

94. Mei HX, Ye Y, Xu HR, Xiang SY, Yang Q, Ma HY, et al. LXA4 Inhibits Lipopolysaccharide-Induced Inflammatory Cell Accumulation by Resident Macrophages in Mice. J Inflamm Res. 2021;14:1375-85.

95. Gu Z, Lamont GJ, Lamont RJ, Uriarte SM, Wang H, Scott DA. Resolvin D1, resolvin D2 and maresin 1 activate the GSK3 3 anti-inflammatory axis in TLR4-engaged human monocytes. Innate Immun. 2016;22:186-95.

96. Serhan CN, Gotlinger K, Hong S, Lu Y, Siegelman J, Baer T, et al. Antiinflammatory actions of neuroprotectin D1/protectin D1 and its natural stereoisomers: assignments of dihydroxy-containing docosatrienes. J Immunol. 2006;176:1848-59.

97. He W, Zhang M, Zhao M, Davis LS, Blackwell TS, Yull F, et al. Increased dietary sodium induces COX2 expression by activating NFkB in renal medullary interstitial cells. Pflugers Arch. 2014;466:357-67.

98. Chen J, Zhao M, He W, Milne GL, Howard JR, Morrow J, et al. Increased dietary $\mathrm{NaCl}$ induces renal medullary PGE2 production and natriuresis via the EP2 receptor. Am J Physiol Ren Physiol. 2008;295:F818-25.

99. Pöschke A, Kern N, Maruyama T, Pavenstädt $H$, Narumiya $S$, Jensen $B L$, et al. The PGE(2)-EP4 receptor is necessary for stimulation of the reninangiotensin-aldosterone system in response to low dietary salt intake in vivo. Am J Physiol Ren Physiol. 2012;303:F1435-42.

100. Limas C, Goldman P, Limas CJ, Iwai J. Effect of salt on prostaglandin metabolism in hypertension-prone and -resistant Dahl rats. Hypertension. 1981;3:219-24.

101. Limas C, Limas CJ. Up-regulation of renal prostaglandin receptors in genetic salt-dependent hypertension. Hypertension. 1986;8:566-71.

102. Lockette WE, Webb RC, Bohr DF. Prostaglandins and potassium relaxation in vascular smooth muscle of the rat. The role of Na-K ATPase. Circ Res. 1980; 46:714-20.

103. Flores D, Liu Y, Liu W, Satlin LM, Rohatgi R. Flow-induced prostaglandin E2 release regulates $\mathrm{Na}$ and $\mathrm{K}$ transport in the collecting duct. Am J Physiol Ren Physiol. 2012;303:F632-8.

104. Dreisbach AW, Rice JC, Japa S, Newman JW, Sigel A, Gill RS, et al. Salt loading increases urinary excretion of linoleic acid diols and triols in healthy human subjects. Hypertension. 2008;51:755-61.

105. Chi XX, Jiang X, Nicol GD. ATP-sensitive potassium currents reduce the PGE2-mediated enhancement of excitability in adult rat sensory neurons. Brain Res. 2007;1145:28-40.

106. Jiang $X$, Zhang YH, Clark JD, Tempel BL, Nicol GD. Prostaglandin E2 inhibits the potassium current in sensory neurons from hyperalgesic Kv1.1 knockout mice. Neuroscience. 2003;119:65-72.

107. Kleinewietfeld M, Hafler DA. The plasticity of human Treg and Th17 cells and its role in autoimmunity. Semin Immunol. 2013;25:305-12.

108. Kleinewietfeld M, Hafler DA. Regulatory T cells in autoimmune neuroinflammation. Immunol Rev. 2014;259:231-44.

109. Binger KJ, Linker RA, Muller DN, Kleinewietfeld M. Sodium chloride, SGK1, and Th17 activation. Pflugers Arch. 2015;467:543-50.

110. Wilck N, Matus MG, Kearney SM, Olesen SW, Forslund K, Bartolomaeus $H$ et al. Salt-responsive gut commensal modulates $T_{H} 17$ axis and disease. Nature. 2017:551:585-9.

111. Arroyo Hornero R, Hamad I, Côrte-Real B, Kleinewietfeld M. The Impact of Dietary Components on Regulatory T Cells and Disease. Front Immunol. 2020;11:253.
112. Haase S, Wilck N, Kleinewietfeld M, Müller DN, Linker RA. Sodium chloride triggers Th17 mediated autoimmunity. J Neuroimmunol. 2019;329:9-13.

113. Asaoka H, Kurokawa J, Furukawa T, Shimokado K. High glucose concentrations impair the activation of $\mathrm{K}+$ channels and proteases in undifferentiated THP-1 monocytes. J Med Dent Sci. 2007;54:97-102.

114. Schlichter L, Sidell N, Hagiwara S. Potassium channels mediate killing by human natural killer cells. Proc Natl Acad Sci U S A. 1986;83:451-5.

115. Sidell N, Schlichter LC, Wright SC, Hagiwara S, Golub SH. Potassium channels in human NK cells are involved in discrete stages of the killing process. J Immunol. 1986;137:1650-8.

116. Khaedir Y, Kartika R. Perspectives on Targeting IL-6 as a Potential Therapeutic Strategy for COVID-19. J Interf Cytokine Res. 2021;41:37-43.

117. Manhiani MM, Seth DM, Banes-Berceli AK, Satou R, Navar LG, Brands MW. The role of IL-6 in the physiologic versus hypertensive blood pressure actions of angiotensin II. Phys Rep. 2015;3:e12595.

118. Ekholm M, Kahan T, Jörneskog G, Brinck J, Wallén NH. Haemostatic and inflammatory alterations in familial hypercholesterolaemia, and the impact of angiotensin II infusion. J Renin-Angiotensin-Aldosterone Syst. 2015;16:328-38.

119. Ekholm M, Kahan T, Jörneskog G, Bröijersen A, Wallén NH. Angiotensin ॥ infusion in man is proinflammatory but has no short-term effects on thrombin generation in vivo. Thromb Res. 2009;124:110-5.

120. Schiffrin EL. The flame that lights the fire: oxidative stress, inflammation, and renal damage in angiotensin II-induced hypertension. Hypertension. 2008; 52:205-6.

121. Harrison DG, Vinh A, Lob H, Madhur MS. Role of the adaptive immune system in hypertension. Curr Opin Pharmacol. 2010;10:203-7.

122. Verlohren S, Muller DN, Luft FC, Dechend R. Immunology in hypertension, preeclampsia, and target-organ damage. Hypertension. 2009;54:439-43.

123. Schiffrin EL. T lymphocytes: a role in hypertension? Curr Opin Nephrol Hypertens. 2010;19:181-6.

124. Shao J, Nangaku M, Miyata T, Inagi R, Yamada K, Kurokawa K, et al. Imbalance of T-cell subsets in angiotensin II-infused hypertensive rats with kidney injury. Hypertension. 2003;42:31-8.

125. Barhoumi T, Kasal DA, Li MW, Shbat L, Laurant P, Neves MF, et al. T regulatory lymphocytes prevent angiotensin II-induced hypertension and vascular injury. Hypertension. 2011;57:469-76.

126. Valencia X, Lipsky PE. CD4CD25FoxP3 regulatory T cells in autoimmune diseases. Nat Clin Pract Rheumatol. 2007;3:619-26.

127. Kikodze N, Pantsulaia I, Rekhviashvili K, lobadze M, Dzhakhutashvili N, Pantsulaia N, et al. Cytokines and T regulatory cells in the pathogenesis of type 1 diabetes. Georgian Med News. 2013;222:29-35.

128. Lunin SM, Khrenov MO, Glushkova OV, Parfenyuk SB, Novoselova TV, Novoselova EG. Immune response in the relapsing-remitting experimental autoimmune encephalomyelitis in mice: The role of the NF-KB signaling pathway. Cell Immunol. 2019;336:20-7.

129. Mohammadi S, Sedighi S, Memarian A. IL-17 is Aberrantly Overexpressed Among Under-treatment Systemic Lupus Erythematosus Patients. Iran J Pathol. 2019 Summer;14:236-42.

130. Lee SY, Lee SH, Seo HB, Ryu JG, Jung K, Choi JW, et al. Inhibition of IL-17 ameliorates systemic lupus erythematosus in Roquin ${ }^{\text {san/san }}$ mice through regulating the balance of TFH cells, GC B cells. Treg and Breg Sci Rep. 2019; 9:5227.

131. Chan CT, Lieu M, Toh BH, Kyaw TS, Bobik A, Sobey CG, et al. Antibodies in the pathogenesis of hypertension. Biomed Res Int. 2014;2014:504045.

132. Kosaraju R, Guesdon W, Crouch MJ, Teague HL, Sullivan EM, Karlsson EA, et al. B Cell Activity Is Impaired in Human and Mouse Obesity and Is Responsive to an Essential Fatty Acid upon Murine Influenza Infection. J Immunol. 2017;198:4738-52.

133. Crouch MJ, Kosaraju R, Guesdon W, Armstrong M, Reisdorph N, Jain R, et al. Frontline Science: A reduction in DHA-derived mediators in male obesity contributes toward defects in select B cell subsets and circulating antibody. J Leukoc Biol. 2019;106:241-57.

134. Ramon S, Gao F, Serhan CN, Phipps RP. Specialized proresolving mediators enhance human B cell differentiation to antibody-secreting cells. I Immunol. 2012;189:1036-42.

135. Ramon S, Baker SF, Sahler JM, Kim N, Feldsott EA, Serhan CN, et al. The specialized proresolving mediator $17-\mathrm{HDHA}$ enhances the antibodymediated immune response against influenza virus: a new class of adjuvant? J Immunol. 2014;193:6031-40.

136. Martins de Lima-Salgado T, Coccuzzo Sampaio S, Cury-Boaventura MF, Curi R. Modulatory effect of fatty acids on fungicidal activity, respiratory burst 
and TNF-a and IL-6 production in $\mathrm{J774}$ murine macrophages. $\mathrm{Br} J$ Nutr. 2011:105:1173-9.

137. Jeffery L, Fisk HL, Calder PC, Filer A, Raza K, Buckley CD, et al. Plasma Levels of Eicosapentaenoic Acid Are Associated with Anti-TNF Responsiveness in Rheumatoid Arthritis and Inhibit the Etanercept-driven Rise in Th17 Cell Differentiation in Vitro. J Rheumatol. 2017:44:748-56.

138. Uchi SH, Yanai R, Kobayashi M, Hatano M, Kobayashi Y, Yamashiro C, et al. Dendritic cells mediate the anti-inflammatory action of omega-3 long-chain polyunsaturated fatty acids in experimental autoimmune uveitis. PLoS One. 2019;14:e0219405.

139. Shoda H, Yanai R, Yoshimura T, Nagai T, Kimura K, Sobrin L, et al. Dietary Omega-3 Fatty Acids Suppress Experimental Autoimmune Uveitis in Association with Inhibition of Th1 and Th17 Cell Function. PLoS One. 2015; 10:e0138241.

140. Chehimi M, Ward R, Pestel J, Robert M, Pesenti S, Bendridi N, et al. Omega-3 Polyunsaturated Fatty Acids Inhibit IL-17A Secretion through Decreased ICAM-1 Expression in T Cells Co-Cultured with Adipose-Derived Stem Cells Harvested from Adipose Tissues of Obese Subjects. Mol Nutr Food Res. 2019:63:e1801148.

141. Mousavi Nasl-Khameneh A, Mirshafiey A, Naser Moghadasi A, Chahardoli R, Mahmoudi M, Parastouei K, et al. Combination treatment of docosahexaenoic acid (DHA) and all-trans-retinoic acid (ATRA) inhibit IL-17 and RORyt gene expression in PBMCs of patients with relapsing-remitting multiple sclerosis. Neurol Res. 2018;40:11-7.

142. Valdez PA, Vithayathil PJ, Janelsins BM, Shaffer AL, Williamson PR, Datta SK. Prostaglandin E2 suppresses antifungal immunity by inhibiting interferon regulatory factor 4 function and interleukin-17 expression in T cells. Immunity. 2012;36:668-79.

143. Duffy MM, Pindjakova J, Hanley SA, McCarthy C, Weidhofer GA, Sweeney EM, et al. Mesenchymal stem cell inhibition of T-helper 17 celldifferentiation is triggered by cell-cell contact and mediated by prostaglandin E2 via the EP4 receptor. Eur J Immunol. 2011;41:2840-51.

144. Boniface K, Bak-Jensen KS, Li Y, Blumenschein WM, McGeachy MJ, McClanahan TK, et al. Prostaglandin E2 regulates Th17 cell differentiation and function through cyclic AMP and EP2/EP4 receptor signaling. J Exp Med. 2009;206:535-48.

145. Davis GK, Fehrenbach DJ, Madhur MS. Interleukin 17A: Key Player in the Pathogenesis of Hypertension and a Potential Therapeutic Target. Curr Hypertens Rep. 2021;23:13.

146. Saleh MA, Norlander AE, Madhur MS. Inhibition of Interleukin 17-A but not Interleukin-17F Signaling Lowers Blood Pressure and Reduces End-organ Inflammation in Angiotensin II-induced Hypertension. JACC Basic TransI Sci. 2016;1 (7):606-16.

147. Norlander AE, Saleh MA, Kamat NV, Ko B, Gnecco J, Zhu L, Dale BL, Iwakura Y, Hoover RS, McDonough AA, Madhur MS. Interleukin-17A Regulates Renal Sodium Transporters and Renal Injury in Angiotensin II-Induced Hypertension. Hypertension. 2016;68:167-74.

148. Karbach S, Croxford AL, Oelze M, Schüler R, Minwegen D, Wegner J, et al. Interleukin 17 drives vascular inflammation, endothelial dysfunction, and arterial hypertension in psoriasis-like skin disease. Arterioscler Thromb Vasc Biol. 2014;34:2658-68.

149. Schüler R, Efentakis P, Wild J, Lagrange J, Garlapati V, Molitor M, et al. T CellDerived IL-17A Induces Vascular Dysfunction via Perivascular Fibrosis Formation and Dysregulation of NO/cGMP Signaling. Oxidative Med Cell Longev. 2019;2019:6721531.

150. Das UN, Begin ME, Ells G, Horrobin DF. Clinical significance of essential fatty acids. Nutrition. 1988:4:337-42.

151. Friedman Z. Polyunsaturated fatty acids in the low-birth-weight infant. Semin Perinatol. 1979;3:341-61.

152. Friedman Z, Danon A, Stahlman MT, Oates JA. Rapid onset of essential fatty acid deficiency in the newborn. Pediatrics. 1976;58:640-9.

153. Das UN. "Cell Membrane Theory of Senescence" and the role of bioactive lipids in aging and aging associated diseases and their therapeutic implications. Biomolecules. 2021;11:241.

154. Li G, Wang X, Yang H, Zhang P, Wu F, Li Y, Zhou Y, Zhang X, Ma H, Zhang W, Li J. a-Linolenic acid but not linolenic acid protects against hypertension: critical role of SIRT3 and autophagic flux. Cell Death Dis. 2020;11:83.

155. Bacova BS, Radosinska J, Wallukat G, Barancik M, Wallukat A, Knezl V, et al. Suppression of $\beta 1$-Adrenoceptor Autoantibodies is Involved in the Antiarrhythmic Effects of Omega-3 Fatty Acids in Male and Female Hypertensive Rats. Int J Mol Sci. 2020;21:526.
156. Chen JX, Xue KY, Xin JJ, Yan X, Li RL, Wang XX, et al. 5-Lipoxagenase deficiency attenuates L-NAME-induced hypertension and vascular remodeling. Biochim Biophys Acta Mol basis Dis. 1865;2019:2379-92.

157. Kriska T, Cepura C, Magier D, Siangjong L, Gauthier KM, Campbell WB. Mice lacking macrophage 12/15-lipoxygenase are resistant to experimental hypertension. Am J Physiol Heart Circ Physiol. 2012;302:H2428-38.

158. Das UN. Arachidonic acid and lipoxin A4 as possible endogenous antidiabetic molecules. Prostaglandins Leukot Essent Fat Acids. 2013;88:201-10.

159. Vara-Messler M, Mukdsi JH, Osieki NI, Benizio E, Repossi GM, Ajayi ElO, et al. Eicosapentaenoic acid prevents salt sensitivity in diabetic rats and decreases oxidative stress. Nutrition. 2020;72:110644.

160. Bathina S, Das UN. PUFAs, BDNF and lipoxin A4 inhibit chemical-induced cytotoxicity of RIN5F cells in vitro and streptozotocin-induced type 2 diabetes mellitus in vivo. Lipids Health Dis. 2019;18:214.

161. Gutierrez AD, Sathyanarayana P, Konduru S, Ye Y, Birnbaum Y, Bajaj M. The effect of pioglitazone treatment on 15-epi-lipoxin A4 levels in patients with type 2 diabetes. Atherosclerosis. 2012;223:204-8.

162. Romanatto T, Fiamoncini J, Wang B, Curi R, Kang JX. Elevated tissue omega3 fatty acid status prevents age-related glucose intolerance in fat- 1 transgenic mice. Biochim Biophys Acta. 1842;2014:186-91.

163. Das UN. Arachidonic acid in health and disease with focus on hypertension and diabetes mellitus: A review. J Adv Res. 2018;11:43-55.

164. Bettelli E, Kom T, Oukka M, Kuchroo VK. Induction and effector functions of $T_{H} 17$ cells. Nature. 2008;453:1051-7.

165. Das UN. Molecular Biochemical Basis of Cancer. NY: Humana; 2020.

166. Laurence A, Tato CM, Davidson TS, Kanno Y, Chen Z, Yao Z, et al. Interleukin-2 signaling via STAT5 constrains T helper 17 cell generation. Immunity. 2007;26:371-81.

167. Mucida D, Park Y, Kim G, Turovskaya O, Scott I, Kronenberg M, et al. Reciprocal TH17 and regulatory T cell differentiation mediated by retinoic acid. Science. 2007;317:256-60.

168. Kleinschek MA, Owyang AM, Joyce-Shaikh B, Langrish CL, Chen Y, Gorman DM, et al. IL-25 regulates Th17 function in autoimmune inflammation. J Exp Med. 2007;204:161-70.

169. Batten M, Li J, Yi S, Kljavin NM, Danilenko DM, Lucas S, et al. Interleukin 27 limits autoimmune encephalomyelitis by suppressing the development of interleukin 17-producing T cells. Nat Immun. 2006;7:929-36.

170. Stumhofer JS, Laurence A, Wilson EH, Huang E, Tato CM, Johnson LM, et al. Interleukin 27 negatively regulates the development of interleukin 17producing T helper cells during chronic inflammation of the central nervous system. Nat Immun. 2006;7:937-45.

171. Wang R, Hasnain SZ, Tong H, Das I, Che-Hao Chen A, Oancea I, et al. Neutralizing IL-23 Is Superior to Blocking IL-17 in Suppressing Intestinal Inflammation in a Spontaneous Murine Colitis Model. Inflamm Bowel Dis. 2015;21:973-84

172. Onishi RM, Gaffen SL. Interleukin-17 and its target genes: mechanisms of interleukin-17 function in disease. Immunology. 2010;129:311-21.

173. Bercea Cl, Cottrell GS, Tamagnini F, McNeish AJ. Omega-3 polyunsaturated fatty acids ( $\omega-3$ PUFAs) and hypertension: a review of vasodilatory mechanisms of DHA and EPA. Br J Pharmacol. 2020. https://doi.org/10.1111/ bph.15336. Epub ahead of print.

174. Das UN. Metabolic Syndrome Pathophysiology: The Role of Essential Fatty Acids. Ames, IA, USA: Wiley-Blackwell Publishers; 2010.

175. Bellenger-Germain S, Poisson JP, Narce M. Antihypertensive effects of a dietary unsaturated FA mixture in spontaneously hypertensive rats. Lipids. 2002;37:561-7.

176. Engler MM, Schambelan M, Engler MB, Ball DL, Goodfriend TL. Effects of dietary gamma-linolenic acid on blood pressure and adrenal angiotensin receptors in hypertensive rats. Proc Soc Exp Biol Med. 1998;218:234-7.

177. Mtabaji JP, Manku MS, Horrobin DF. Abnormalities in dihomo-gammalinolenic acid release in the pathogenesis of hypertension. Am J Hypertens. 1993;6(6 Pt 1):458-62.

178. Sato M, Aoki-Saito H, Fukuda H, Ikeda H, Koga Y, Yatomi M, et al. Resolvin E3 attenuates allergic airway inflammation via the interleukin-23-interleukin17A pathway. FASEB J. 2019;33:12750-9.

179. Kim JY, Lim K, Kim KH, Kim JH, Choi JS, Shim SC. N-3 polyunsaturated fatty acids restore Th17 and Treg balance in collagen antibody-induced arthritis. PLoS One. 2018;13:e0194331.

180. Bi X, Li F, Liu S, Jin Y, Zhang X, Yang T, et al. $\omega-3$ polyunsaturated fatty acids ameliorate type 1 diabetes and autoimmunity. J Clin Invest. 2017; 127:1757-71 
181. Monk JM, Hou TY, Turk HF, McMurray DN, Chapkin RS. n3 PUFAs reduce mouse CD4+ T-cell ex vivo polarization into Th17 cells. J Nutr. 2013;143: 1501-8.

182. Siresha B, Naveen KVG, Poorani R, Sailaja P, Devi HD, Monika S, et al. Resolvin D1 ameliorates nicotinamide-streptozotocin-induced type 2 diabetes mellitus by its anti-inflammatory action and modulating PI3K/Akt/ mTOR pathway in the brain. Arch Med Res. 2020;51:492-503.

183. Bathina S, Das UN. Resolvin D1 Decreases Severity of StreptozotocinInduced Type 1 Diabetes Mellitus by Enhancing BDNF Levels, Reducing Oxidative Stress, and Suppressing Inflammation. Int J Mol Sci. 2021;22:1516.

184. Schulte F, Asbeutah AA, Benotti PN, Wood GC, Still C, Bistrian BR, et al. The relationship between specialized pro-resolving lipid mediators, morbid obesity and weight loss after bariatric surgery. Sci Rep. 2020;10:20128.

185. Kwon Y. Immuno-Resolving Ability of Resolvins, Protectins, and Maresins Derived from Omega-3 Fatty Acids in Metabolic Syndrome. Mol Nutr Food Res. 2020;64:e1900824.

186. Samuels JS, Holland L, López M, Meyers K, Cumbie WG, McClain A, et al. Prostaglandin E2 and IL-23 interconnects STAT3 and RoRy pathways to initiate Th17 CD4 ${ }^{+}$T-cell development during rheumatoid arthritis. Inflamm Res. 2018;67:589-96.

187. Ueharaguchi Y, Honda T, Kusuba N, Hanakawa S, Adachi A, Sawada Y, et al. Thromboxane $A_{2}$ facilitates IL-17A production from $V_{\gamma 4}{ }^{+} \gamma \delta T$ cells and promotes psoriatic dermatitis in mice. J Allergy Clin Immunol. 2018;142:6803.

188. Shi Q, Yin Z, Zhao B, Sun F, Yu H, Yin X, et al. PGE2 Elevates IL-23 Production in Human Dendritic Cells via a CAMP Dependent Pathway. Mediat Inflamm. 2015;2015:984690.

189. Sheibanie AF, Tadmori I, Jing H, Vassiliou E, Ganea D. Prostaglandin E2 induces IL-23 production in bone marrow-derived dendritic cells. FASEB J. 2004;18:1318-20.

190. Qian X, Gu L, Ning H, Zhang Y, Hsueh EC, Fu M, et al. Increased Th17 cells in the tumor microenvironment is mediated by IL-23 via tumor-secreted prostaglandin E2. J Immunol. 2013;190:5894-902.

191. Alvarez C, Amaral MM, Langellotti C, Vermeulen M. Leukotriene C(4) prevents the complete maturation of murine dendritic cells and modifies interleukin-12/interleukin-23 balance. Immunology. 2011;134:185-97.

192. Haworth O, Cernadas M, Yang R, Serhan CN, Levy BD. Resolvin E1 regulates interleukin 23, interferon-gamma and lipoxin A4 to promote the resolution of allergic airway inflammation. Nat Immunol. 2008;9:873-9.

193. Maekawa T, Hosur K, Abe T, Kantarci A, Ziogas A, Wang B, et al. Antagonistic effects of IL-17 and D-resolvins on endothelial Del-1 expression through a GSK-3ß-C/EBPß pathway. Nat Commun. 2015;6:8272.

194. Poloso NJ, Urquhart P, Nicolaou A, Wang J, Woodward DF. PGE2 differentially regulates monocyte-derived dendritic cell cytokine responses depending on receptor usage (EP2/EP4). Mol Immunol. 2013; 54(3-4):284-95.

195. Stahl RA, Attallah AA, Bloch DL, Lee JB. Stimulation of rabbit renal PGE2 biosynthesis by dietary sodium restriction. Am J Phys. 1979;237:F344-9.

196. Attallah AA, Stahl RA, Bloch DL, Ambrus JL, Lee JB. Inhibition of rabbit renal prostaglandin E2 biosynthesis by chronic potassium deficiency. J Lab Clin Med. 1981;97:205-12.

197. Kumar KV, Das UN. Effect of cis-unsaturated fatty acids, prostaglandins and free radicals on angiotensin converting enzyme activity in vitro. Proc Soc Exp Biol Med. 1997;214:374-9.

198. Berra-Romani R, Faris P, Negri S, Botta L, Genova T, Moccia F. Arachidonic Acid Evokes an Increase in Intracellular $\mathrm{Ca}^{2+}$ Concentration and Nitric Oxide Production in Endothelial Cells from Human Brain Microcirculation. Cells. 2019;8:689.

199. Tamaoki J, Tagaya E, Yamawaki I, Konno K. Lipoxin A4 inhibits cholinergic neurotransmission through nitric oxide generation in the rabbit trachea. Eur J Pharmacol. 1995;287:233-8.

200. Spite M, Norling LV, Summers L, Yang R, Cooper D, Petasis NA, et al. Resolvin D2 is a potent regulator of leukocytes and controls microbial sepsis. Nature. 2009;461:1287-91.

201. Yu Z, Ng VY, Su P, Engler MM, Engler MB, Huang Y, et al. Induction of renal cytochrome $\mathrm{P} 450$ arachidonic acid epoxygenase activity by dietary gammalinolenic acid. J Pharmacol Exp Ther. 2006;317:732-8.

202. Takagi Y, Sugimoto T, Kobayashi M, Shirai M, Asai F. High-salt intake ameliorates hyperglycemia and insulin resistance in WBN/Kob-Leprfa/fa rats: A new model of type 2 diabetes mellitus. J Diabetes Res. 2018;2018: 3671892 .
203. Namekawa J, Takagi Y, Wakabayashi K, Nakamura Y, Watanabe A, Nagakubo $D$, et al. Effects of high-fat diet and fructose-rich diet on obesity, dyslipidemia and hyperglycemia in the WBN/Kob-Lepr ${ }^{\text {fa }}$ rat, a new model of type 2 diabetes mellitus. J Vet Med Sci. 2017;79:988-91.

204. Takagi Y, Kadowaki H, Kobayashi I, Ito K, Ito K, Shirai M, et al. Effects of highsodium intake on systemic blood pressure and vascular responses in spontaneously diabetic WBN/Kob-Lepr ${ }^{\text {fa/fa }}$ rats. Clin Exp Pharmacol Physiol. 2017:44:305-12.

205. Jeddi S, Gheibi S, Carlström M, Kashfi K, Ghasemi A. Long-term coadministration of sodium nitrite and sodium hydrosulfide inhibits hepatic gluconeogenesis in male type 2 diabetic rats: Role of PI3K-Akt-eNOS pathway. Life Sci. 2021;265:118770.

206. Alvarado-Vásquez N, Zapata E, Alcázar-Leyva S, Massó F, Montaño LF. Reduced NO synthesis and eNOS mRNA expression in endothelial cells from newborns with a strong family history of type 2 diabetes. Diabetes Metab Res Rev. 2007 Oct;23(7):559-66.

207. Vecoli C, Novelli M, Pippa A, Giacopelli D, Beffy P, Masiello P, et al. Partia Deletion of eNOS Gene Causes Hyperinsulinemic State, Unbalance of Cardiac Insulin Signaling Pathways and Coronary Dysfunction Independently of High Fat Diet. PLOS ONE. 2014;9:e104156.

208. Motoshima H, Wu X, Mahadev K, Goldstein BJ. Adiponectin suppresses proliferation and superoxide generation and enhances eNOS activity in endothelial cells treated with oxidized LDL. Biochem Biophys Res Commun. 2004;315:264-71.

209. Awazawa M, Ueki K, Inabe K, Yamauchi T, Kubota N, Kaneko K, et al. Adiponectin enhances insulin sensitivity by increasing hepatic IRS-2 expression via a macrophage-derived IL-6-dependent pathway. Cell Metab. 2011:13:401-12.

210. Ravussin E. Adiponectin enhances insulin action by decreasing ectopic fat deposition. Pharm J. 2002;2:4-7.

211. Liu Z, Ma X, llyas I, Zheng X, Luo S, Little PJ, et al. Impact of sodium glucose cotransporter 2 (SGLT2) inhibitors on atherosclerosis: from pharmacology to pre-clinical and clinical therapeutics. Theranostics. 2021;11:4502-15.

212. Meng Z, Liu X, Li T, Fang T, Cheng Y, Han L, et al. The SGLT2 inhibitor empagliflozin negatively regulates IL-17/IL-23 axis-mediated inflammatory responses in T2DM with NAFLD via the AMPK/mTOR/autophagy pathway. Int Immunopharmacol. 2021;94:107492.

213. Sukhanov S, Higashi Y, Yoshida T, Mummidi S, Aroor AR, Jeffrey Russell J, et al. The SGLT2 inhibitor Empagliflozin attenuates interleukin-17A-induced human aortic smooth muscle cell proliferation and migration by targeting TRAF3IP2/ROS/NLRP3/Caspase-1-dependent IL-1 $\beta$ and IL-18 secretion. Cell Signal. 2021;77:109825.

214. Ziegler SF, Buckner JH. FOXP3 and the regulation of Treg/Th17 differentiation. Microbes Infect. 2009;11:594-8.

215. An JH, Song WJ, Li Q, Kim SM, Yang Jl, Ryu MO, et al. Prostaglandin $E_{2}$ secreted from feline adipose tissue-derived mesenchymal stem cells alleviate DSS-induced colitis by increasing regulatory T cells in mice. BMC Vet Res. 2018;14:354

216. Jin S, Chen H, Li Y, Zhong H, Sun W, Wang J, et al. Maresin 1 improves the Treg/Th17 imbalance in rheumatoid arthritis through miR-21. Ann Rheum Dis. 2018;77:1644-52.

217. Chen L, Wu X, Zhong J, Li D. L161982 alleviates collagen-induced arthritis in mice by increasing Treg cells and down-regulating Interleukin-17 and monocyte-chemoattractant protein-1 levels. BMC Musculoskelet Disord. 2017:18:462.

218. Bai M, Zhang L, Fu B, Bai J, Zhang Y, Cai G, et al. IL-17A improves the efficacy of mesenchymal stem cells in ischemic-reperfusion renal injury by increasing Treg percentages by the COX-2/PGE2 pathway. Kidney Int. 2018; 93:814-25.

219. Luo B, Han F, Xu K, Wang J, Liu Z, Shen Z, et al. Resolvin D1 Programs Inflammation Resolution by Increasing TGF- $\beta$ Expression Induced by Dying Cell Clearance in Experimental Autoimmune Neuritis. J Neurosci. 2016;36: 9590-603.

220. Carlsson JA, Wold AE, Sandberg AS, Östman SM. The Polyunsaturated Fatty Acids Arachidonic Acid and Docosahexaenoic Acid Induce Mouse Dendritic Cells Maturation but Reduce T-Cell Responses In Vitro. PLoS One. 2015;10: e0143741.

221. Han SC, Koo DH, Kang NJ, Yoon WJ, Kang GJ, Kang HK, et al. Docosahexaenoic Acid Alleviates Atopic Dermatitis by Generating Tregs and IL-10/TGF- $\beta$-Modified Macrophages via a TGF- $\beta$-Dependent Mechanism. J Invest Dermatol. 2015;135:1556-64. 
222. Qin S, Wen J, Bai XC, Chen TY, Zheng RC, Zhou GB, et al. Endogenous n-3 polyunsaturated fatty acids protect against imiquimod-induced psoriasis-like inflammation via the IL-17/IL-23 axis. Mol Med Rep. 2014;9:2097-104.

223. Liu W, Li H, Zhang X, Wen D, Yu F, Yang S, et al. Prostaglandin I2-IP signalling regulates human Th17 and Treg cell differentiation. Prostaglandins Leukot Essent Fat Acids. 2013;89:335-44.

224. Wang L, Zhao L, Lv J, Yin Q, Liang X, Chu Y, et al. BLT1-dependent alveolar recruitment of $\mathrm{CD} 4(+) C D 25(+)$ Foxp3(+) regulatory $T$ cells is important for resolution of acute lung injury. Am J Respir Crit Care Med. 2012;186:989-98.

225. Soontrapa K, Honda T, Sakata D, Yao C, Hirata T, Hori S, et al. Prostaglandin E2-prostaglandin E receptor subtype 4 (EP4) signaling mediates UV irradiation-induced systemic immunosuppression. Proc Natl Acad Sci U S A. 2011;108:6668-73.

226. Kong W, Yen JH, Ganea D. Docosahexaenoic acid prevents dendritic cell maturation, inhibits antigen-specific Th1/Th17 differentiation and suppresses experimental autoimmune encephalomyelitis. Brain Behav Immun. 2011;25: 872-82.

227. Yessoufou A, Plé A, Moutairou K, Hichami A, Khan NA. Docosahexaenoic acid reduces suppressive and migratory functions of $C D 4+C D 25+$ regulatory T-cells. J Lipid Res. 2009;50:2377-88.

228. Chen H, Qin J, Wei P, Zhang J, Li Q, Fu L, et al. Effects of leukotriene B4 and prostaglandin E2 on the differentiation of murine Foxp3+ T regulatory cells and Th17 cells. Prostaglandins Leukot Essent Fat Acids. 2009;80:195-200.

229. Bryn T, Yaqub S, Mahic M, Henjum K, Aandahl EM, Taskén K. LPS-activated monocytes suppress T-cell immune responses and induce FOXP3+ T cells through a COX-2-PGE2-dependent mechanism. Int Immunol. 2008;20:235-45.

230. Mahic M, Yaqub S, Johansson CC, Taskén K, Aandahl EM. FOXP3+CD4+ CD25+ adaptive regulatory $T$ cells express cyclooxygenase-2 and suppress effector T cells by a prostaglandin E2-dependent mechanism. J Immunol. 2006;177:246-54.

231. Baratelli F, Lin Y, Zhu L, Yang SC, Heuzé-Vourc'h N, Zeng G, et al. Prostaglandin E2 induces FOXP3 gene expression and T regulatory cell function in human CD4+ T cells. J Immunol. 2005:175:1483-90.

232. Sharma S, Yang SC, Zhu L, Reckamp K, Gardner B, Baratelli F, et al. Tumor cyclooxygenase-2/prostaglandin E2-dependent promotion of FOXP3 expression and CD4+CD25+ T regulatory cell activities in lung cancer. Cancer Res. 2005;65:5211-20.

\section{Publisher's Note}

Springer Nature remains neutral with regard to jurisdictional claims in published maps and institutional affiliations.

Ready to submit your research? Choose BMC and benefit from:

- fast, convenient online submission

- thorough peer review by experienced researchers in your field

- rapid publication on acceptance

- support for research data, including large and complex data types

- gold Open Access which fosters wider collaboration and increased citations

- maximum visibility for your research: over $100 \mathrm{M}$ website views per year

At $\mathrm{BMC}$, research is always in progress.

Learn more biomedcentral.com/submissions 